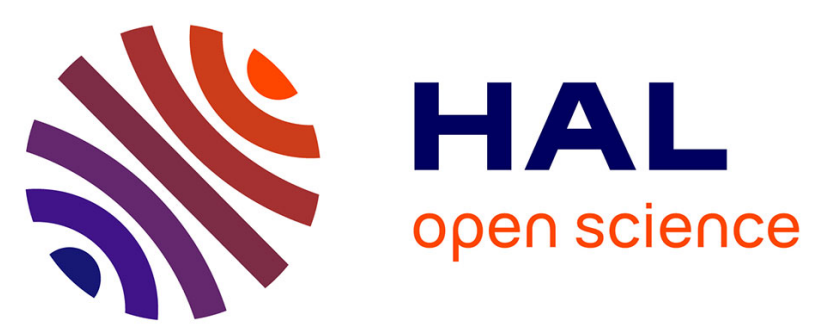

\title{
Assessing ecological habitat structure from local to landscape scales using synthetic aperture radar
}

Julie Betbeder, Laurence Hubert-Moy, Françoise Burel, Samuel Corgne, Jacques Baudry

\section{- To cite this version:}

Julie Betbeder, Laurence Hubert-Moy, Françoise Burel, Samuel Corgne, Jacques Baudry. Assessing ecological habitat structure from local to landscape scales using synthetic aperture radar. Ecological Indicators, 2015, 52, pp.545-557. 10.1016/j.ecolind.2014.11.009 . hal-01110146

\section{HAL Id: hal-01110146 \\ https://hal-univ-rennes1.archives-ouvertes.fr/hal-01110146}

Submitted on 6 Mar 2015

HAL is a multi-disciplinary open access archive for the deposit and dissemination of scientific research documents, whether they are published or not. The documents may come from teaching and research institutions in France or abroad, or from public or private research centers.
L'archive ouverte pluridisciplinaire HAL, est destinée au dépôt et à la diffusion de documents scientifiques de niveau recherche, publiés ou non, émanant des établissements d'enseignement et de recherche français ou étrangers, des laboratoires publics ou privés. 


\title{
Assessing ecological habitat structure from local to landscape scales using Synthetic Aperture Radar
}

\author{
Julie Betbeder ${ }^{1}{ }^{*}$, Laurence Hubert-Moy ${ }^{1}$, Françoise Burel ${ }^{2}$, Samuel Corgne ${ }^{1}$, Jacques \\ Baudry $^{3}$
}

1 LETG Rennes COSTEL UMR 6554 LETG/OSUR, Université Rennes 2, Place du recteur Henri Le Moal, 35043, Rennes Cedex, France. E-Mails: julie.betbeder@univ-rennes2.fr ; samuel.corgne@uhb.fr ; laurence.moy@uhb.fr.

2 UMR 6553 ECOBIO, CNRS Université de Rennes 1, Campus de Beaulieu, 35042 Rennes Cedex, France. E-Mail: francoise.burel@univ-rennes1.fr.

3 INRA SAD-PAYSAGE, 65, rue de St-Brieuc CS 84215, 35042 Rennes Cedex, France. EMail: jacques.baudry@rennes.inra.fr.

* Author to whom correspondence should be addressed; E-Mail: julie.betbeder@univrennes2.fr (B.J.); Tel.: +33-2-99-14-18-47; Fax: +33- 2-99-14-18-95.

\begin{abstract}
Ecological studies need accurate environmental data such as vegetation characterization, landscape structure and organization, to predict and explain the spatial distribution of biodiversity. Few ecological studies use remote sensing data to assess the biophysical or structural properties of vegetation to understand species distribution. To date, Synthetic Aperture Radar (SAR) data have seldom been used for ecological applications. However, these sensors provide data allowing access to the inner structure of vegetation which is a key information in ecology. The objective of this article is to compare the predictive power of ecological habitat structure variables derived from a TerraSAR-X image, an aerial photograph and a SPOT-5 image for species distribution. The test was run with a hedgerow network in Brittany and assessed the spatial distribution of the forest ground carabid beetles which inhabit these hedgerows. The results confirmed that radar and optical images can be indifferently used to extract hedgerow network and derived landscape metrics (hedgerow density, network grain) useful to explain the spatial distribution of forest carabid beetles. In comparison with passive optical remotely sensed data, VHSR SAR images provide new data to characterize vegetation structure and more particularly hedgerow canopy cover, a variable known to explain the spatial distribution of carabid beetles in an agricultural landscape, but not yet quantified at a fine scale. The hedgerow canopy cover derived from the SAR image is
\end{abstract}


a strong predictor of the abundance of forest carabid beetles at two scales i.e. a local scale and a landscape scale.

\section{Keywords}

biodiversity, remote sensing, forest carabid beetles, hedgerow canopy cover, landscape scale, quantitative maps

\section{Introduction}

Ecological studies aiming to explain and predict species distribution or spatial variability of species richness over landscapes need accurate data for quantifying the structure and organization of habitats (St-Louis et al., 2009). Understanding spatial species distribution is directly linked to the ability to characterize the environmental conditions that drive species distribution. Remotely sensed data offer a unique opportunity to provide environmental information with complete coverage, at different spatial and temporal resolutions and extents, such as land cover classification (Kerr and Ostrovsky 2003) and vegetation biophysical properties (Turner et al. 2003; Jacquemoud et al. 2009) or structural properties (Lee and Pottier, 2009; Imhoff et al., 1997).

The use of remotely sensed data for ecological applications has increased in recent years, for instance to predict species richness (Kerr and Ostrovsky, 2003; Levanoni et al. 2011), or map plant assemblages (Betbeder et al. 2014a; Pu 2009; Clark et al. 2005). Most of the time, the imagery used in ecology is optical remotely sensed imagery (Kerr and Ostrovsky 2003), for instance the Normalized Difference Vegetation Index (NDVI) is used for many ecological applications (Pettorelli et al., 2014). NDVI provides information on vegetation distribution and dynamics and can be used to predict animal distribution, abundance etc. (Pettorelli et al., 2005). Other remote sensing data, such as SAR (Synthetic Aperture Radar) and LIDAR (Light Detection And Ranging) images, offer new opportunities to characterize vegetation structure over a whole landscape. Indeed, LIDAR remote sensing has the ability to acquire three dimensional measurements of the landscape surface of a study site at a fine spatial resolution, which is useful for estimating a variety of vegetation features (such as tree height, volume, biomass) (Heinzel and Koch 2011; Müller and Brandl 2009). However, LIDAR is costly meaning that regular time-series monitoring is operationally constrained. Synthetic Aperture Radar (SAR) data are easier to acquire and provide a reliable alternative to optical images, 
because they are not sensitive to visibility conditions and they can be acquired by day or night (Ulaby, 1990). As radar sensors with very high spatial resolution (VHSR) are all weather instruments, they increase the possibility of frequent data collection allowing inter and intra annual monitoring at fine scales. Moreover, they allow access to the inner structure of vegetation (Betbeder et al. 2014b). Images acquired by these sensors should allow an increase in the amount and accuracy of ecological information extracted from remote sensing data (Kasischke et al., 1997) and improve their utility in ecological studies.

The objective of this article is to test the information provided by SAR imagery as compared to aerial photographs and SPOT-5 imagery for ecological applications and more specifically to explain species abundance. We ran the test with a hedgerow network in Brittany, France. Hedgerows fulfill ecological, social and economic functions such as control of soil erosion, landscape beautification, wood production, microclimatic effects, water quality and conservation of biodiversity (Baudry et al. 2000). Hedgerow networks play a key role in habitat connectivity for some species and thus influence the degree of fragmentation of the landscape (Petit and Burel 1998). Furthermore, hedgerow structure (tree and shrub cover, width) is a major variable to determine habitat quality for plants and animals (Le Cœur et al., 2002). A recurrent question in landscape ecology is to determine the "forest" character of such hedgerow network landscapes (Forman and Baudry, 1984). Hedgerows where shade and humidity are permanent because of the vegetation density can be forest-like habitats for small, less mobile species. This can be reinforced by the landscape structure as in fine grain landscapes wind speed is lower, therefore evapotranspiration is also lower. This fosters the ability of hedgerows to harbor species thriving in shady, cool habitats (Burel 1989). Most studies therefore use maps of networks and a qualification of hedgerow structure. Hedgerow structure is mostly described for small areas from field measurements. Because this process is too time-consuming, hedgerow structure is estimated over landscapes in a semi-quantitative manner (e.g. Defra 2007). The estimation of tree density, cover, shrub cover in the field is subject to the observers' bias. Furthermore, it is performed on segments of hedgerow networks corresponding to a "hedgerow" defined as either the segment between two connections or the segment along a field defined by its land cover (Baudry et al. 2000). So these segments are of different sizes and the parameters used to describe them are estimated at a scale that is not always relevant to the study species that inhabit them. Therefore the internal homogeneity or heterogeneity of hedgerows is not assessed. Moreover, in many ecological studies, information on the fragmentation of hedgerow networks and canopy cover is often retrieved 
in the field using accurate ground surveys (Baudry et al. 2000). Therefore, this type of landscape is a good candidate to run our test, as structural patterns at different scales from the individual hedgerow to the network drive species composition.

Most of the time, wooded hedgerows are digitized by hand from conventional airborne photographs (Burel and Baudry 1990) over small study sites, which is a time-consuming approach. Some studies dealing with the mapping of landscape features from remote sensing data have shown that VHSR satellite images are suitable for automatic hedgerow mapping (Vannier and Hubert-Moy 2010; Aksoy et al. 2008; Bargiel 2013). Vannier et al. (2011) i) show the influence of spatial and spectral resolutions of optical images for hedgerow extraction and ii) explore how predictions of species distributions might be affected by the information derived from the extractions realized with different remotely sensed data.

Betbeder et al. 2014b show the potential of TerraSAR-X imagery to i) detect hedgerow networks and ii) quantify the hedgerow canopy cover. They established a relationship between a polarimetric indicator, derived from the SAR data, i.e. the Shannon entropy, and hedgerow canopy cover. This study supplies information about the possibilities for the determination of ecological metrics based on remote sensing data. We hypothesized that TerraSAR-X imagery would provide more valuable information than that of aerial photographs or SPOT-5 images as it explores both the inner structure of the hedgerow and the network structure. As a biological model, we chose forest carabid beetles as their ecology is well known (Thiele, 1977; Burel, 1989; Aviron et al. 2005), along with their relations with the hedgerow network landscape structure. Ground beetles (Coleoptera, Carabidae) are an appropriate group to select as indicators of environmental quality or change (Kromp, 1999; Pearson, 1994).

\section{Materials and methods}

\subsection{Study site}

The investigated area is a Long Term Ecological Research site named 'Pleine Fougères' (130 $\mathrm{km}^{2}$ ), located in the southern part of the Bay of the Mont-Saint-Michel, France (Fig. 1). The area has a temperate oceanic climate with an average precipitation of around $600 \mathrm{~mm} / \mathrm{year}$. This study focuses on a hedgerow network which offers contrasted structures related to management structures (Baudry and Jouin 2003) and which is dominated by Castanea sativa 
and Quercus robur in generally planted on an earthern bank. The hedgerow network's density is about $74 \mathrm{~m} / \mathrm{ha}$ (Vannier et al. 2011).

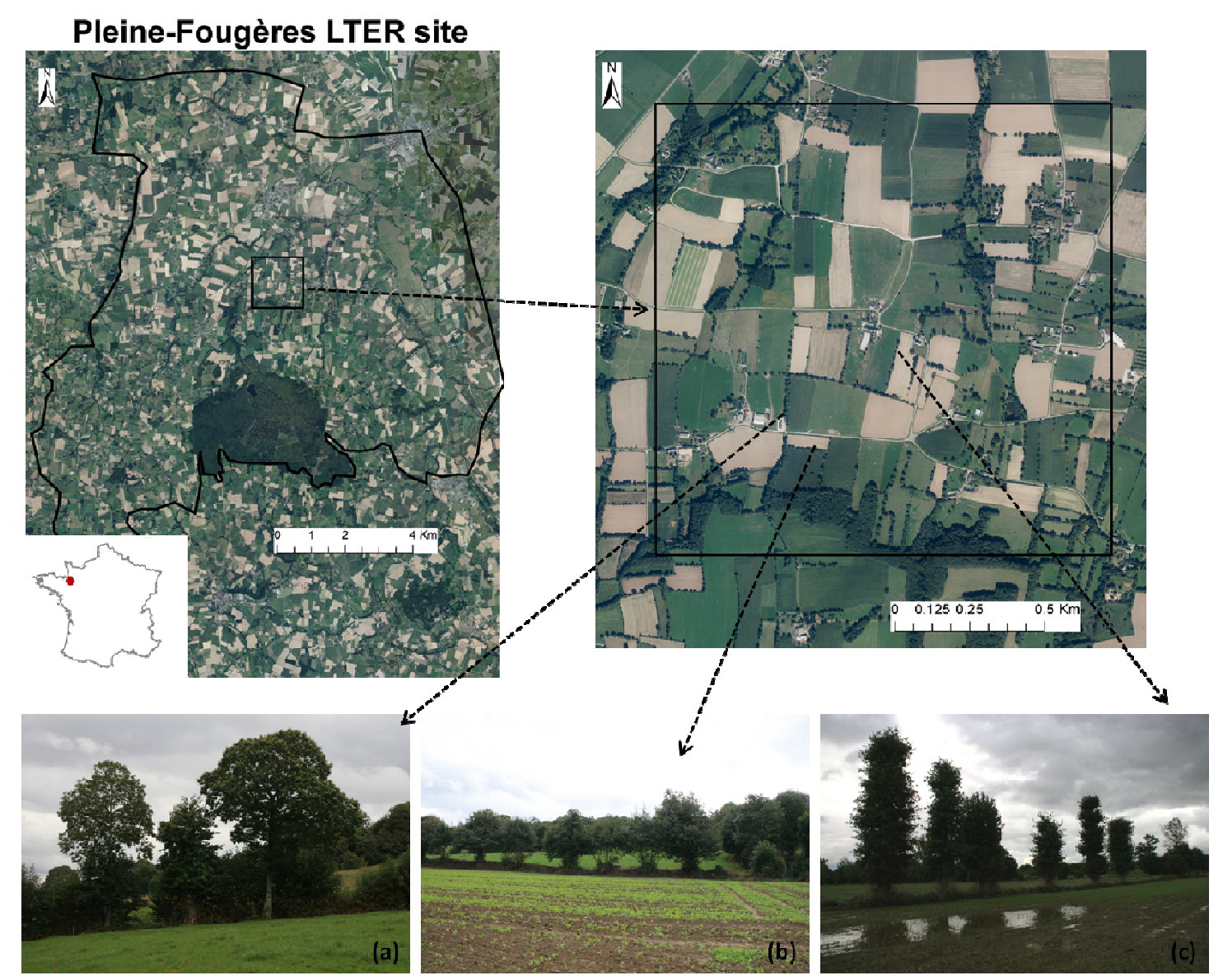

Figure 1. Location of the study site focusing on a sub-network where biological data sampling has been performed. This sub-network presents different canopy structures (a) (c), with (a) or without (b) (c) underlying shrubs and pruned trees.

\subsection{Remote sensing data}

Three types of remotely sensed data were acquired: one SAR TerraSAR-X image, one optical SPOT-5 image and aerial photographs. Their characteristics are summarized in Table 1. Remotely sensed data were acquired over two years: 2012 and 2013. We made the assumption that only small changes occurred in the hedgerow network during this time period. The SAR image was acquired during the leaf-off period (i.e. February) to assess the inner structure of the canopy (Betbeder et al., 2014b) 
Table 1. Characteristics of remote sensing data

\begin{tabular}{|c|c|c|c|}
\hline & TerraSAR X & SPOT-5 & Aerial photographs \\
\hline Dates & $02 / 16 / 2013$ & $09 / 30 / 2012$ & $07 / 14 / 2013$ \\
\hline Spatial resolution (m) & 1.5 (High resolution spotlight) & 2.5 & 0.5 \\
\hline \multirow[t]{4}{*}{ Band } & Band X $(3.1 \mathrm{~cm}, 9.65 \mathrm{GHz})$ & B1 (green): 0.5-0.59 $\mu \mathrm{m}$ & Panchromatic \\
\hline & & B2 (red): 0.61-0.68 $\mu \mathrm{m}$ & \\
\hline & & B3 (NIR): 0.78-0.89 $\mu \mathrm{m}$ & \\
\hline & & B4 (MIR):1.58-1.75 $\mu \mathrm{m}$ & \\
\hline Polarization & Dual polarization (HH/VV) & & \\
\hline Incidence angle & $37^{\circ}$ (Right Ascending) & $8.5^{\circ}$ & Nadir \\
\hline Type of map & $\begin{array}{l}\text { Raster ( } 1.5 \mathrm{~m} \text { resolution) with } \\
\text { hedgerows as objects with } \\
\text { canopy cover measured by the } \\
\text { Shannon entropy polarimetric } \\
\text { indicator }\end{array}$ & $\begin{array}{l}\text { Raster (2.5 m resolution) } \\
\text { with hedgerows as } \\
\text { homogeneous objects }\end{array}$ & $\begin{array}{l}\text { First a vector map } \\
\text { with hedgerows as } \\
\text { polylines, then, } \\
\text { rasterization at } 5 \mathrm{~m} \\
\text { resolution }\end{array}$ \\
\hline
\end{tabular}

\subsection{Carabid surveys}

The sampling was conducted in 45 hedgerows from April to September 2013. The hedgerows were chosen to maximize the diversity of the hedgerow canopy cover sampled. The hedgerow canopy cover was quantified using SAR images (Betbeder et al. 2014b). Indeed, Betbeder et al., $2014 \mathrm{~b}$ showed that the Shannon entropy (SE) index derived from SAR images is directly related to the canopy cover, high values of SE corresponding to high canopy cover and viceversa. Betbeder et al., 2014 b studied a landscape similar to the landscape in this study. It presented different hedgerow canopy cover (correlated with SE values comprised between -2 and 2). Figure 2 presents the different values of canopy covers of the hedgerow network on the study site and those of the sampled hedgerows as detected by SAR images. The histogram (Figure 2. b) of the SE values computed on the hedgerows sampled shows that the values of SE are quite heterogeneous (ranging from -2 to 1 ). These values are representative of the canopy cover types present in the whole hedgerow network of the study site (Betbeder et al., 
2014 b) , which ShE values range from -5 to 3 with a majority of values being comprised between -2 and 1, Figure 2. a). Adult carabid beetles were caught with pitfall traps filled with monopropylene glycol solution. In each hedgerow, we set up one sampling station made up of three pitfall traps set $4 \mathrm{~m}$ apart, located at the top of earthen banks and collected every 2 weeks, during 24 weeks, thus for a total of 12 sampling period.
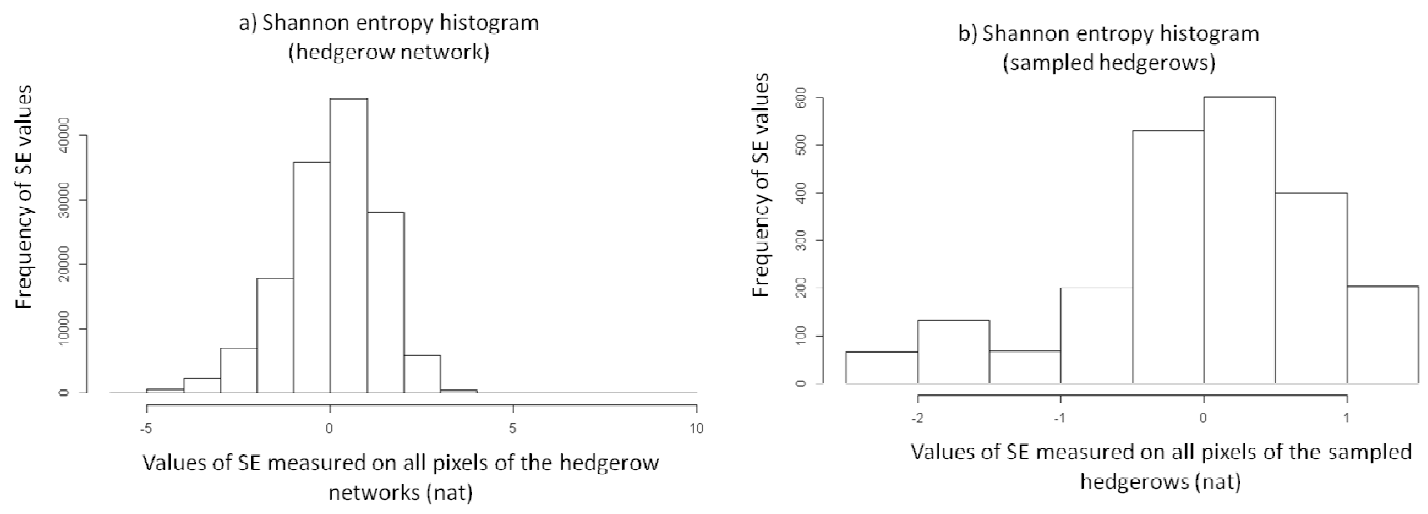

Figure 2. Hedgerow canopy cover detected by SAR images (Shannon entropy (ShE) values for all hedgerow pixels) over the entire study site (a) and hedgerow canopy cover detected by SAR images in sampled hedgerows for carabid surveys (Shannon entropy values for all pixels of sampled hedgerows) (b).

The mean Euclidian distance between sampling points was on average $60 \mathrm{~m}$ (min: 35 $\mathrm{m}$ and max: $230 \mathrm{~m}$ ), much greater than the possible movement of ground beetles: Loreau and Nolf (1993) report that a non-flying beetle such as Abax parallelepipedus, one of the most abundant forest species, can travel about 1.8 m per day. Loreau and Nolf, 1993 estimate that their home range in a forest is about $660 \mathrm{~m}^{2}, 25 \times 25 \mathrm{~m}$. Charrier et al., 1997 found similar results for woods and a range of 15 to $20 \mathrm{~m}$ in hedgerows. The species has a maximum activity-density in spring and autumn.

\subsection{Hedgerow network extraction}

The first part of the methodology consists of extracting the hedgerow network using satellite and airborne remote sensing data (Fig. 3) (aerial photographs). Once the data had been preprocessed in order to correct any distortion due to the characteristics of the imaging sensor 
and imaging conditions, various parameters were derived from the images to be used in the classification process to extract the hedgerow network.

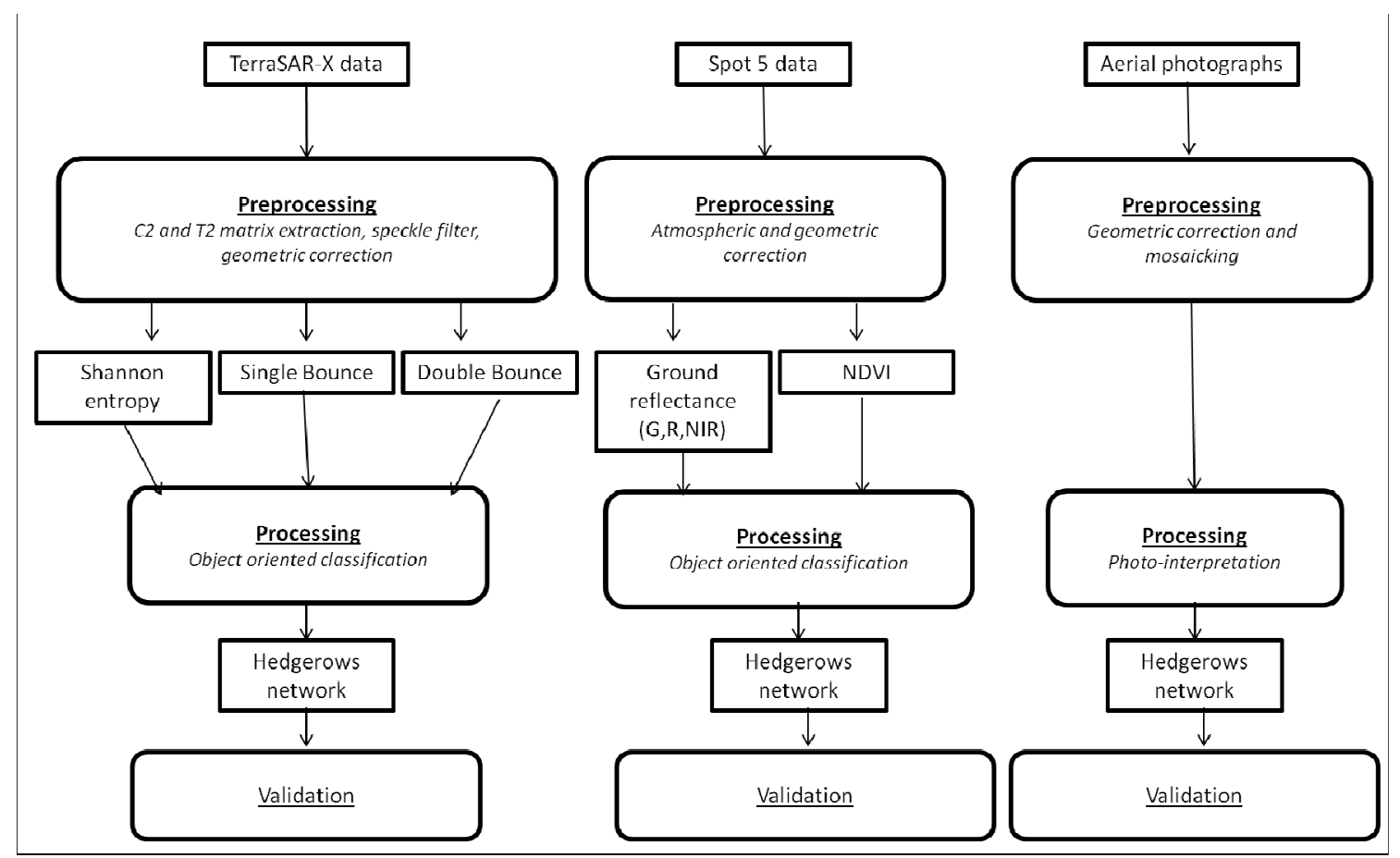

Figure 3. Workflow of pre-processing and processing of images for hedgerow network extraction.

\subsubsection{Pre-processing of remote sensing data}

Polarimetric images are sensitive to object orientation and scattering properties. In synthetic aperture radar (SAR) polarimetry, the emitted and received states of polarization change during data collection ( $\mathrm{HH}, \mathrm{HV}, \mathrm{VH}$ and $\mathrm{VV}$ for full polarimetric data), providing the phase and magnitude of the backscattered signal which is related to the material properties of the studied object (roughness, orientation, structure...). Although three major scattering mechanisms can be studied (Fig. 4), in our case we only investigated single and double bounce scattering mechanisms because the TerraSAR-X data only contained $\mathrm{HH}$ and VV information (and not HV used to study volume scattering). 

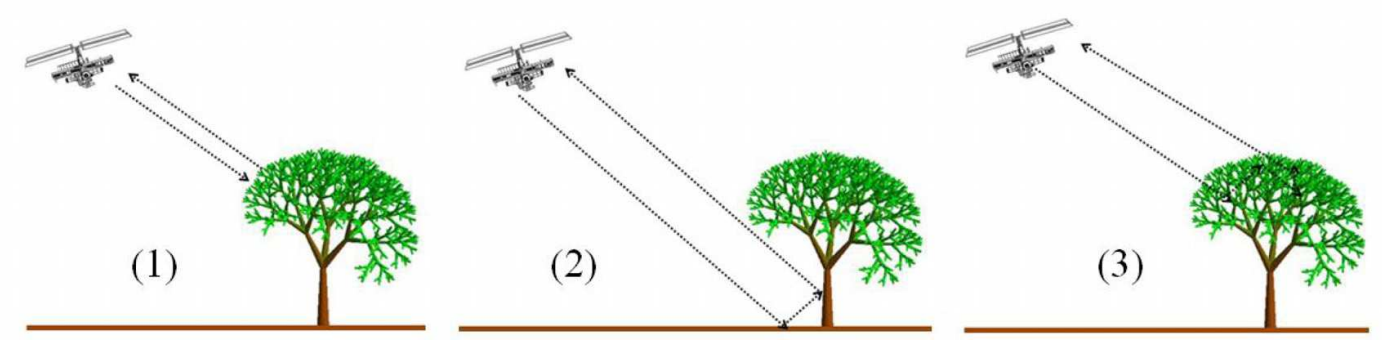

Figure 4. The three major scattering mechanisms studied with polarimetric data: (1) Single bounce from a flat surface backscattered towards the radar, (2) Double bounce from a flat surface that is horizontal with an adjacent vertical surface (for instance the ground and a trunk) and (3) Volume scattering from randomly oriented objects (for instance the canopy trees).

A $2 \times 2$ covariance $\left(C_{2}\right)$ matrix was firstly extracted from the SAR scattering matrix (Fig. 3) image using PolSARpro v4.0 software (Polarimetric SAR Data Processing and Educational Toolbox) (Pottier and Ferro-Famil 2012). A Lee refined filter (Lee, 1981) was then applied to this image using a window of $3 * 3$ pixels to reduce speckle noise. The geocoding process was in this case directly applied to the elements of the $2 \times 2 C_{2}$ matrix which were independent of the polarimetric absolute phase (Lee and Pottier 2009). From the covariance matrix we measured the Shannon entropy (ShE) (Lee and Pottier 2009). ShE values were transformed using a natural logarithm. This corresponds to the random scattering of a pixel which can be due to the variation of backscattering power or the variation of backscattering polarization. According to Betbeder et al. (2014b) this polarimetric indicator is directly linked to the canopy cover. In parallel, a $2 \mathrm{X} 2$ coherency $\left(\mathrm{T}_{2}\right)$ matrix was extracted from the scattering matrix $S$ using the Pauli spin elements $\mathbf{k}_{\mathbf{T}}$ (Lee and Pottier 2009). The first element of the diagonal $\left|\mathbf{S}_{\mathrm{HH}}+\mathbf{S}_{\mathrm{vv}}\right|^{\mathbf{Z}}$ and the second $\left|\mathbf{S}_{\mathrm{HH}}-\mathbf{S}_{\mathrm{Vv}}\right|^{\mathbf{2}}$ were used to study the single bounce and double bounce mechanisms respectively.

Concerning the SPOT-5 image, radiometric and atmospheric corrections were performed by applying the 5S model (Tanré et al., 1990), and geometric correction was undertaken (Fig. 3) using ArcGIS 10.0 (Esri Inc.). All the data were georeferenced based on the Lambert 93 conformal conic system, and the Root Mean Square Error was less than 1 pixel. One vegetation index, the Normalized Difference Vegetation Index (NDVI) which detects live green plant canopies, was calculated (Tucker, 1979).

The aerial photographs, acquired by an Ultra Light Motorized (ULM) summer flight in 2013, were georeferenced and mosaicked. 
2.4.2 Processing of remote sensing data for hedgerow extraction

An object-oriented approach was used to classify the SPOT-5 and TerraSAR-X images to extract wooded hedgerows (Benz et al., 2004) using eCognition software (Definiens Imaging) (Fig. 3). The object-oriented approach consists in classifying homogeneous groups of pixels using spatial and contextual information (Blaschke and Strobl 2001).

The rule set developed to classify the radar image used the multi-threshold segmentation algorithm that segments the image into objects based on a threshold value that splits the image object domain and classifies the resulting image objects based on a defined pixel value threshold. This threshold can be user-defined, dividing the selected set of pixels into two subsets so that spectral heterogeneity between objects is increased to a maximum. The Shannon entropy image was used to eliminate grassland and crops and the single bounce to eliminate bare soils in order to identify hedgerows (Betbeder et al. 2014b). Indeed, the Shannon entropy presents higher values for grassland and crops than for bare soils because the number of backscattering mechanisms that occur in these two land use classes is higher than that for bare soils. Single bounce was used to eliminate bare soils because it is the dominant backscattering mechanism for this type of land surface.

Concerning the SPOT-5 optical image, we applied a multi-threshold segmentation that generates objects, based on scale, shape and reflectance values. Then, a threshold for the Normalized Difference Vegetation Index (NDVI) band was defined to extract hedgerows. Indeed, hedgerows present higher NDVI values than other land cover types (i.e. grasslands, crops and bare soils).

The hedgerow network map derived from the aerial photographs was produced from a manual digitization using ArcGIS 10.0 software. In the resulting map, each hedgerow is represented by a polyline, the common way to represent hedgerows (Forman and Baudry 1984). In this case, only the location of hedgerows is available, but there is no information concerning the tree canopy width or its internal structure. The map was rasterized with a $5 \mathrm{~m}$ resolution for subsequent analysis.

In conclusion, we obtained a map of the network with hedgerows represented by lines from the aerial photographs; a map of the network and information on the tree canopy width from the SPOT-5 image and a map of the network with information on the tree canopy width and a 
characterization of the internal structure of hedgerows (Shannon entropy (ShE)) from the TerraSAR-X image (Table 1).

Thirty points in hedgerows and 30 points in agricultural plots were taken in the field using a DGPS (Trimble, accuracy $0.10 \mathrm{~m}$ ). The accuracy of the classification was defined using a precision index (percentage of correctly classified pixels) since we considered only 2 classes.

\subsection{Global evaluation of the relationship between remote sensing data and the distribution of carabid beetles}

The second part of the methodology consisted in evaluating landscape metrics and variables derived from remote sensing data to explain the spatial distribution of forest carabid beetles (Fig. 5). We calculated landscape metrics characterizing the hedgerow network using optical satellite images and aerial photographs. In parallel, not only the same landscape metrics were derived from the SAR data but also variables characterizing the hedgerow canopy cover (Betbeder et al., 2014 b).

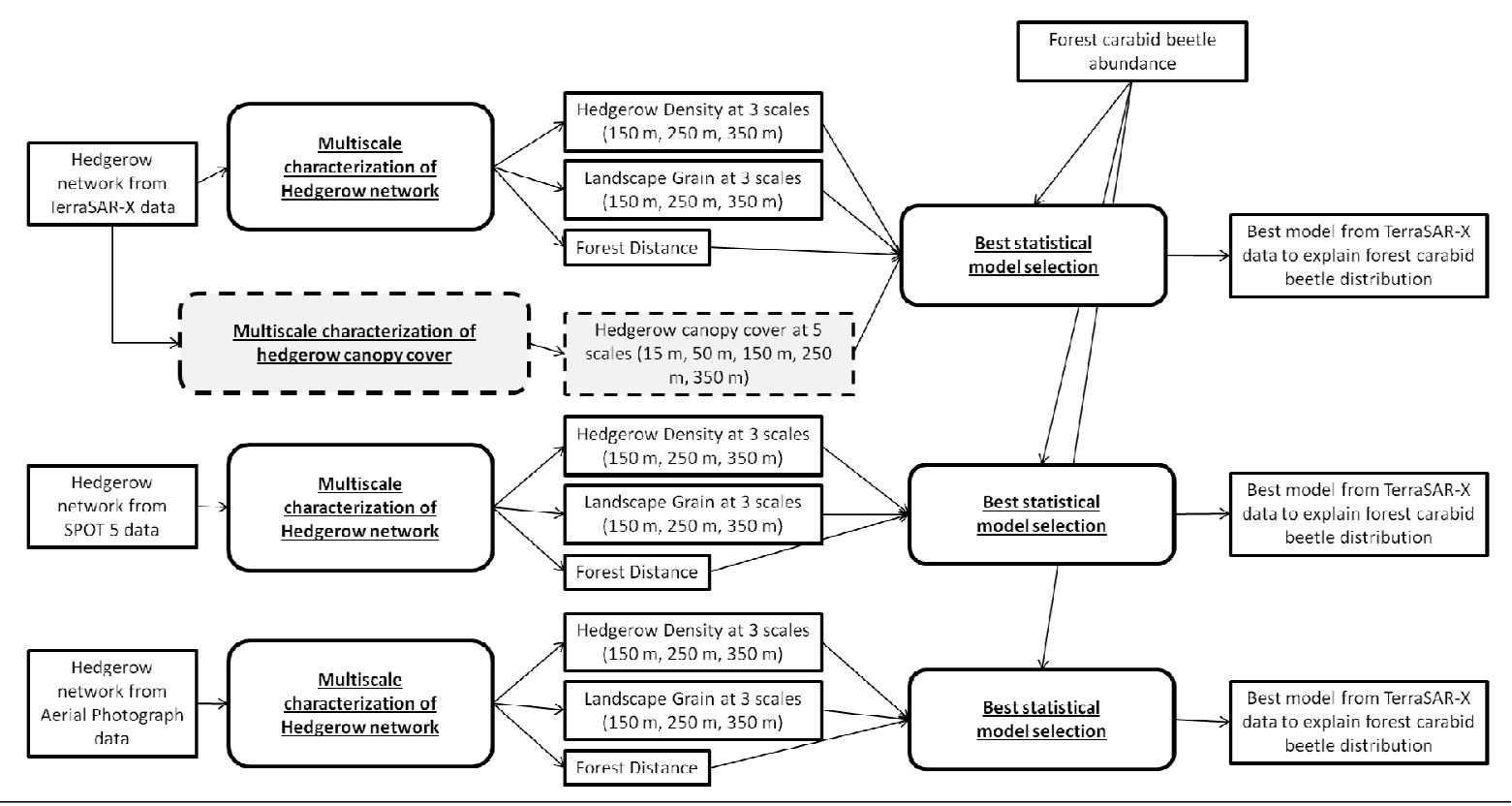

Figure 5. Workflow of the global evaluation of the relationship between remote sensing data and the spatial distribution of carabid beetles

2.5.1 Multiscale characterization of hedgerow network structure

We characterized the hedgerow network structure with the three maps derived from the three sensors using two landscape metrics: hedgerow density and landscape grain at different scales 
using different windows sizes $(150 \mathrm{~m}, 250 \mathrm{~m}, 350 \mathrm{~m}$ in diameter). The hedgerow density corresponds to the area covered by hedgerows in the different windows. The landscape grain is the size of the mesh of the network, ranging from many small elements (fine grain) to larger ones (coarse grain) (as defined by Forman and Godron, 1986, adapted by Vannier et al. 2011 for hedgerow networks). Hedgerow networks have many discontinuities and, therefore, do not comprise "closed meshes", i.e. the space between hedgerows. The size of these meshes controls the local climate by reducing, wind speed and capturing the energy from the sun. We use "grain" as a surrogate of these meshes to characterize the more or less open character of the landscape. Hedgerow density alone is not sufficient as for similar densities the spatial distribution of hedgerows, thence the landscape grain, may be different. In practice, every pixel of the raster map was classified according to its distance from the closest hedgerow. Four distance classes were used to classify each pixel: (1) hedgerows (2) less than $50 \mathrm{~m}$, (3) proportional to hedgerow length, 50-100 m and (4) more than $100 \mathrm{~m}$. Between 50 and $100 \mathrm{~m}$ the influence of hedgerows decreases rapidly and for distances greater than $100 \mathrm{~m}$, the influence of hedgerows (10 times their height) is negligible (Caborn, 1955). We then computed the number of pixels of the different land use classes centered on carabid sampling sites in different sizes of windows $(150 \mathrm{~m}, 250 \mathrm{~m}, 350 \mathrm{~m})$. The following formula, which was used to measure the landscape grain, is an adaptation of the methods developed in Vannier et al. (2011).

Landscape grain $=\frac{\operatorname{class}(3)+\operatorname{class}(4)}{\operatorname{class}(2)+\operatorname{class}(3)}$

This means that when the number of pixels located over $50 \mathrm{~m}$ from hedgerows in the landscape is high, the landscape is coarse-grained, and when it is small (minimum 0) the grain is fine.

\subsubsection{Multiscale characterization of hedgerow canopy covers}

Betbeder et al. (2014b) established a relationship between the Shannon entropy (ShE) derived from the TerraSAR-X image and the hedgerow canopy cover. As explained in the material section, this metric has high values for high canopy cover (when the density of branches is high and they are interwoven). Conversely, a simple structure of straight branches with low canopy cover, for example, yields a low value of this metric. The aim of this section is to 
identify the range of ShE values that represent the hedgerow canopy cover present on the study site that best explain the forest carabid beetle distribution.

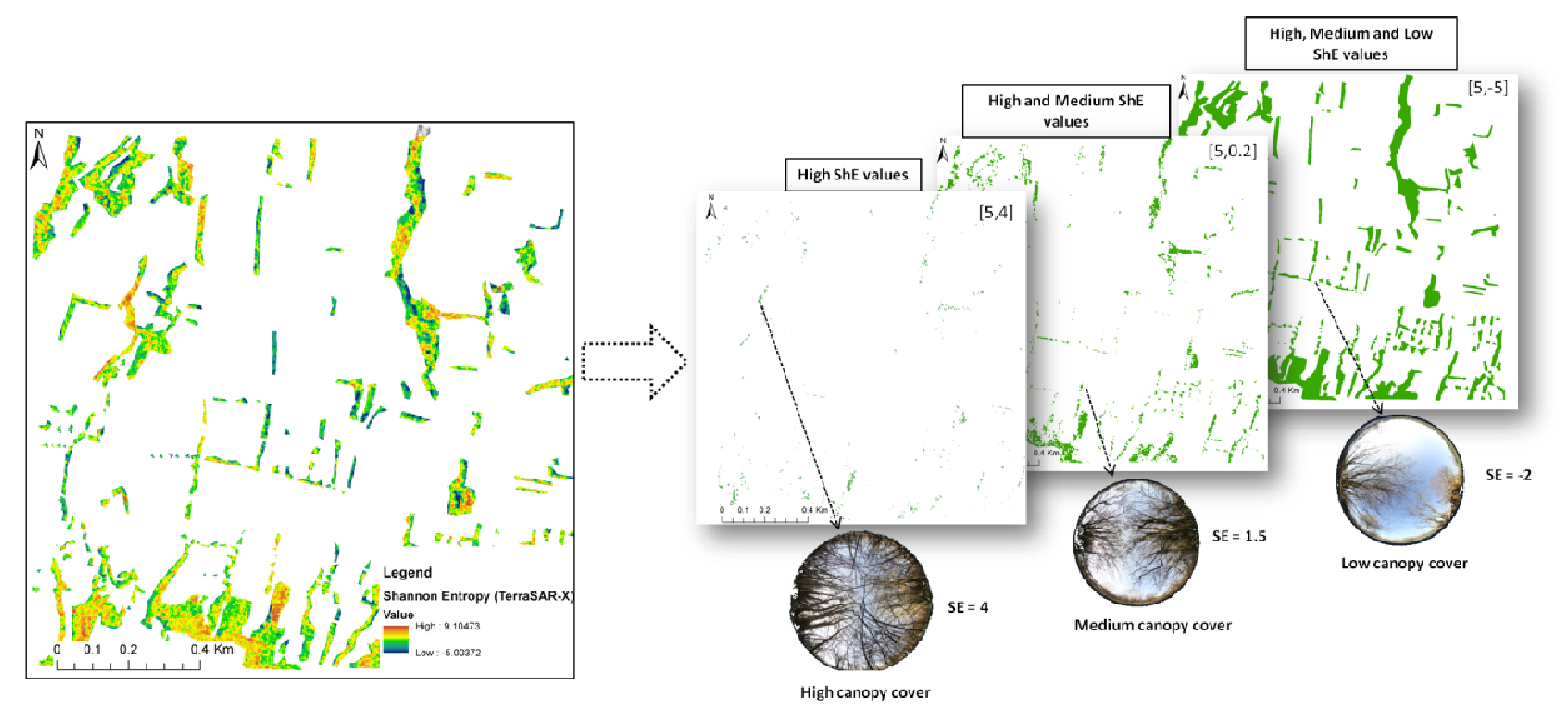

Figure 6. Examples of maps produced from ShE (TerraSAR-X image). Each one shows a different range of hedgerow canopy cover.

Different maps were produced presenting different ranges of ShE values, and thus different hedgerow canopy cover (Fig. 6). ShE varied between 5 and -5 nat for hedgerow objects on our study site. 5 represents the highest level of canopy cover and -5 the lowest level of canopy cover (e.g. trimmed hedges). We know that forest carabid beetles are sensitive to internal hedgerow structure (Burel, 1987). Starting from the maximum ShE values (i.e. 5), representing the highest level of canopy cover, we split the range of values by adding 0.1 to the highest value for each new map. For instance, the values in the first range were comprised between 5 and 4.9, in the second between 5 and 4.8, in the third between 5 and 4.7, etc, until the largest range possible comprised between 5 and -5 was reached (Fig. 6). The Shannon entropy values of the sampled hedgerows encountered in our study site were comprised between -2 and 2 (Fig. 2). Betbeder et al., 2014 b showed that variations in canopy cover appeared mainly at break values of 0.5 . An interval of 0.1 was chosen to be fine enough to detect changes in canopy cover. In other words, we created different maps presenting different hedgerow canopy cover from the highest range of canopy cover on our study site, adding increasing variability of hedgerow canopy cover. In total, 150 maps were produced. Each map represents different hedgerow canopy structures from the highest canopy cover for high ShE values to more heterogeneous canopy covers for high, medium and low ShE values (Fig. 6). For each of the 150 maps presenting the hedgerow canopy cover, we measured the area 
covered by these structures for 5 window sizes $(15 \mathrm{~m}, 50 \mathrm{~m}, 150 \mathrm{~m}, 250 \mathrm{~m}, 350 \mathrm{~m})$ centered on the carabid beetle samples. Statistical analyses were conducted in order to find the ShE "value range" that best explains the spatial distribution of carabid beetles and thus to create the hedgerow canopy cover metric. Following Legendre and Legendre (2012), carabid beetle abundance was cubic root transformed to assess normal distribution. Generalized linear mixed models (GLMM) were then built to evaluate the effect of hedgerow canopy cover on the abundance of forest carabid beetles. Model fits were estimated using the coefficient of determination (R-squared) and p-values in order to identify the hedgerow canopy structures that best explained the abundance of forest carabid beetles. We used a significance threshold of $\mathrm{p}<0.05$.

2.5.3 Relationship between metrics derived from the three sensors and the distribution of abundance of forest carabid beetles

We tested the different landscape metrics and variables derived from the remotely sensed data that best explained the spatial distribution of forest carabid beetles for each type of remote sensing data. A summary of the explanatory variables tested is presented in Table 2.

Table 2. Explanatory quantitative variables tested on the distribution of the abundance of forest carabid beetles

\begin{tabular}{|c|l|l|l|}
\hline & \multicolumn{1}{|c|}{ Aerial photographs } & \multicolumn{1}{c|}{ SPOT-5 } & \multicolumn{1}{c|}{ TerraSAR-X } \\
\cline { 2 - 3 } & Hedgerow density & Hedgerow density & Hedgerow density \\
Explanatory & $(150 \mathrm{~m}, 250 \mathrm{~m}, 350 \mathrm{~m})$ & $(150 \mathrm{~m}, 250 \mathrm{~m}, 350 \mathrm{~m})$ & $(150 \mathrm{~m}, 250 \mathrm{~m}, 350 \mathrm{~m})$ \\
variables & Landcape grain & Landcape grain & Landcape grain \\
& $(150 \mathrm{~m}, 250 \mathrm{~m}, 350 \mathrm{~m})$ & $(150 \mathrm{~m}, 250 \mathrm{~m}, 350 \mathrm{~m})$ & $(150 \mathrm{~m}, 250 \mathrm{~m}, 350 \mathrm{~m})$ \\
& & & Hedgerow canopy cover \\
& & & $(15 \mathrm{~m}, 50 \mathrm{~m}, 150 \mathrm{~m}, 250 \mathrm{~m}, 350 \mathrm{~m})$ \\
& & & \\
\hline
\end{tabular}

Generalized linear mixed models (GLMM) were built to assess the effect of the hedgerow network structure from the aerial photographs and SPOT-5 image, and to assess the effect of the hedgerow network structure and hedgerow canopy cover from the TerraSAR-X image on the abundance of forest carabid beetles. We performed a model selection based on the comparison of the values of the corrected Akaike information criterion (AICc) (Burnham 
et al. 2011) and adjusted r-squared to test the effects of hedgerow network structure and internal hedgerow structure at different scales on carabid beetle abundance. All possible models containing any subset of explanatory factors for each sensor were fitted to the data and ranked according to their AICc values from the model with the lowest AICc and the highest adjusted r-squared (Burnham and Anderson 2002). We used a significance threshold of $\mathrm{p}<$ 0.05. We also conducted test to determine whether the model residuals displayed spatial autocorrelation using an I-Moran test (Carsten, et al., 2007; Legendre and Legendre, 2012). The correlation between the different explanatory variables (for each sensor), measured at different scales, always yielded an r-squared below 0.7 for similar variables (density or grain). For the two types of variables, density and grain, the maximum r-squared value was 0.5 (Appendix A).

Finally, to quantify the predictive power of the best model, a cross-validation was performed using the "leave-one-out" method (Hastier et al., 2009). In this method all but one sampling surveys of carabid beetle abundance were used to obtain multiple regression parameters. The sampling survey which was left out was then estimated (predicted value) using the regression model and the predicted abundance value was compared with the observed sample carabid abundance (using sampling points). The process was repeated 45 times (as many times as there is sample carabid abundance). Thus, model robustness was assessed by calculating the rsquared and Root Mean Square Error (RMSE) measured using the leave-one-out method (differences between the predicted values of the abundance of forest carabid beetles and the real abundance of carabid beetles measured in the fields). All analyses were performed in the R 2.9.0 software package (R core Development Core team 2010) and MuMIn 1.7.11 and qcc packages.

\section{Results}

\subsection{Carabid beetles}

We captured 9786 individuals belonging to 71 species. 1572 individuals belonging to nine forest carabid beetle species were found: Abax parallelepipedus, Carabus granulatus, Carabus intricatus, Carabus nemoralis, Carabus problematicus, Pterostichus nigrita, Pterostichus niger, Elaphrus Riparius, Pristonychus terricola. Individuals of Abax parallelepipedus represented $78 \%$ of the total. Forest carabids were found at 39 of the 45 sampling points, with an average of 30 individuals per sampling point. 


\subsection{Hedgerow extraction}

The accuracy of the hedgerow network classification was high, with an overall match of $92 \%$ and $90 \%$ for SPOT-5 and TerraSAR-X respectively (Table 3). Any errors were mainly due to an underestimation of trimmed hedgerows, because the spatial resolution of SPOT-5 $(2.5 \mathrm{~m})$ and TerraSAR-X $(1.5 \mathrm{~m})$ is too coarse to detect them.

Table 3. Hedgerow classification accuracy

\begin{tabular}{cccc}
\hline Sensor & $\begin{array}{c}\text { Percentage of correctly } \\
\text { detected pixels }\end{array}$ & $\begin{array}{c}\text { Percentage of over- } \\
\text { estimated pixels }\end{array}$ & $\begin{array}{c}\text { Percentage of } \\
\text { under-estimated } \\
\text { pixels }\end{array}$ \\
\hline SPOT-5 & $92 \%$ & $0 \%$ & $8 \%$ \\
TerraSAR-X & $90 \%$ & $0 \%$ & $10 \%$ \\
\hline
\end{tabular}

We note that hedgerow discontinuity detected by the SAR image (Fig. 7) was mainly due to the presence of gaps in hedgerows (as shown in the picture in Figure 1) (Betbeder et al., 2014 b). These gaps are due to agricultural practices performed on hedgerows. This point is interesting, because compared to optical data mostly acquired in summer during cloudless periods when trees have leaves that hide gaps in hedgerows, radar data better detect hedgerow discontinuities, which constitutes a reliable source of information to study species distribution patterns (Burel \& Baudry, 1990). 


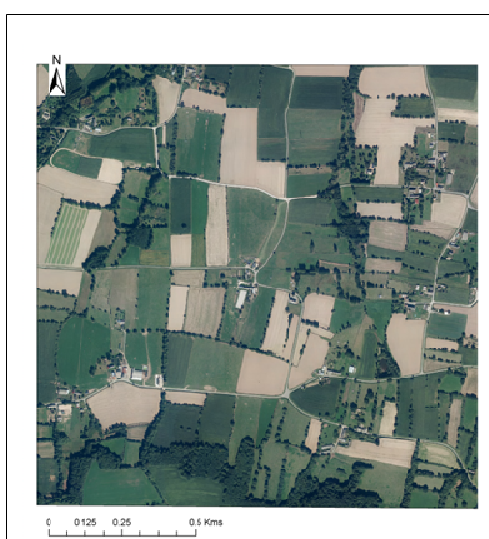

(1) Aerial photographs

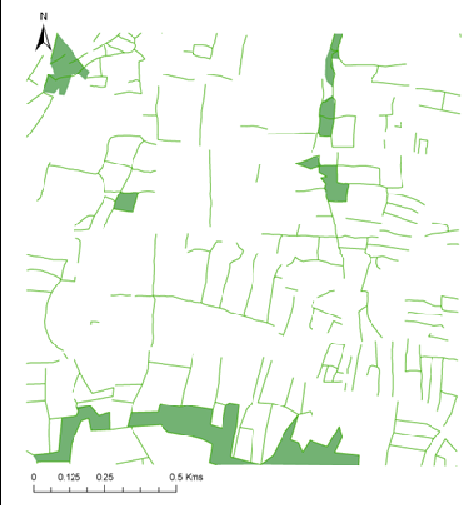

Hedgerow map

from aerial photographs

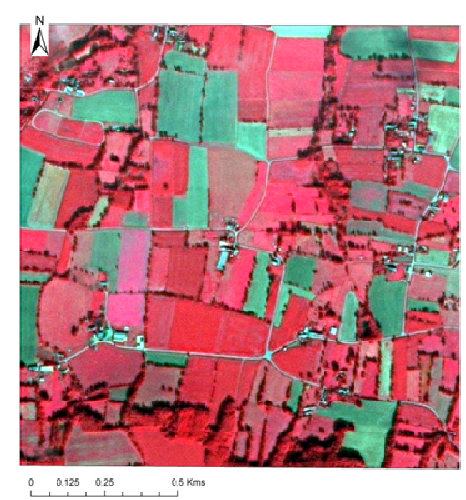

(2) SPOT-5

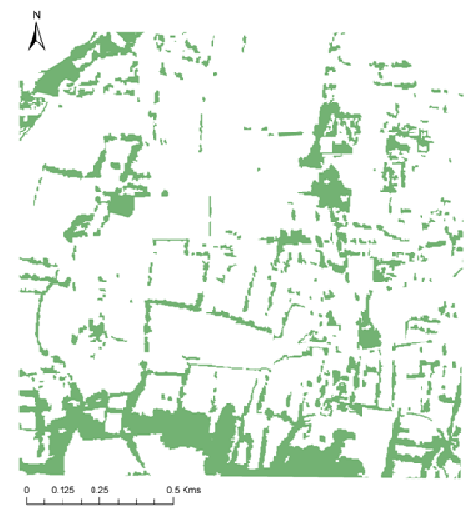

Hedgerow map from SPOT-5

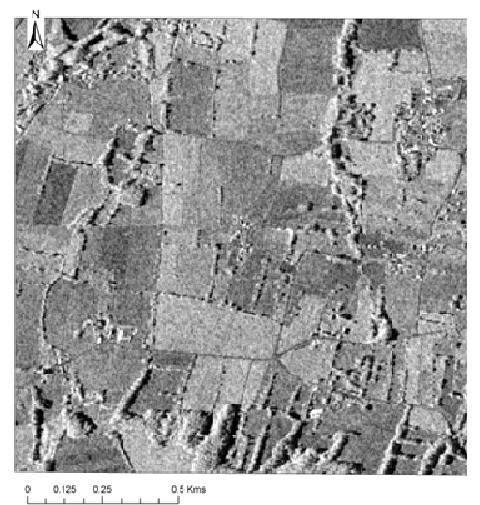

(3) TerraSAR-X

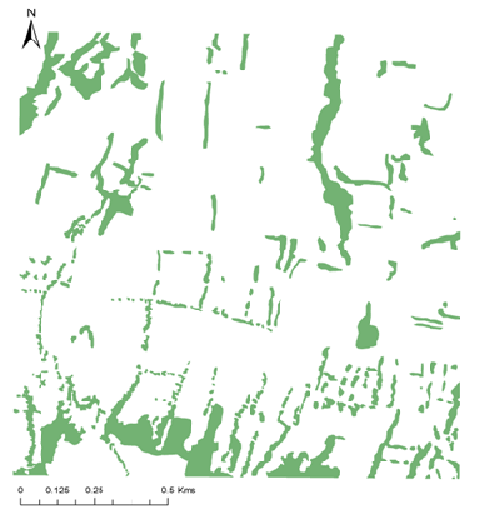

Hedgerow map from TerraSAR-X

Figure 7. Hedgerow map classifications from the aerial photographs, SPOT-5 and TerraSAR-X images

Linear regressions between the same landscape metrics extracted from the three sensors were tested (Appendix B). Landscape metrics derived from satellite imagery are highly correlated, especially for hedgerow density, and less correlated for landscape grain. Correlations between landscape metrics derived from the aerial photographs and landscape metrics derived from satellite data are lower, comprised between 0.4 and 0.8 (Appendix B).

\subsection{Relationships between forest carabid beetles and metrics characterizing the hedgerow network structure and hedgerow canopy cover at multiple scales}

We first determined the range of Shannon entropy values that represent the hedgerow canopy cover, derived from the TerraSAR-X image, which was the best predictor of the abundance of forest carabids. We then looked, independently for each sensor, for the combination of variables that best explained the distribution of forest carabids. 
3.3.1 Range of "hedgerow canopy cover" that best explains spatial distribution of forest carabid beetles

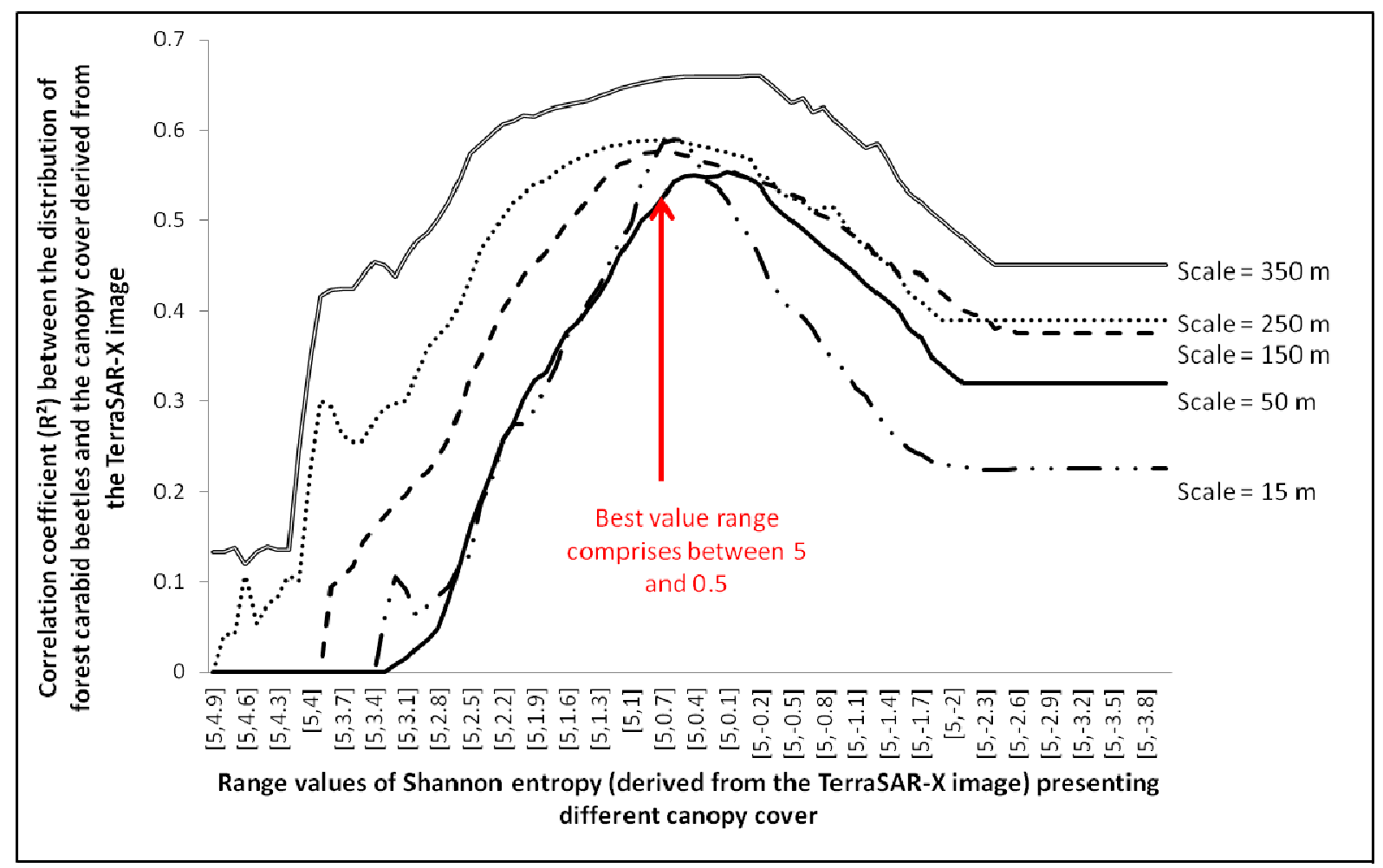

Figure 8. Results of linear regressions between ShE-derived maps and abundance of carabid beetles

Figure 8 shows the evolution of the correlation coefficient $\left(\mathrm{R}^{2}\right)$ between the repartition of forest carabid beetles and different range of canopy covers derived from the TerraSAR-X image (ShE) in buffers of different sizes (i.e. buffer sizes of $15 \mathrm{~m}, 50 \mathrm{~m}, 150 \mathrm{~m}, 250 \mathrm{~m}, 350$ $\mathrm{m}$ ). We can observe (Figure 8) that at all scales the value range of ShE that best explained the spatial distribution of carabid beetles was comprised between 5 and 0.5 values (r-squared around 0.6). In other words, whatever the scale, one range of ShE values (from 0.5 to 5) that corresponds to high canopy cover (Betbeder et al., 2014 b) best explains the distribution of forest carabid beetles in the studied landscape. This metric (area covered by pixels corresponding to high canopy cover, at different scales) was included into the SAR model as an explanatory variable in addition to the metrics characterizing the hedgerow network structure.

3.3.2 Global evaluation of the relationship between remotely sensed data and the distribution of forest carabid beetles 
We firstly evaluated the predictive power of the metrics characterizing the hedgerow network structure (i.e. hedgerow density and landscape grain at 3 scales) derived from the SPOT-5 optical image and from the aerial photograph to explain the spatial distribution of forest carabid beetles. According to the AICc and the adjusted r-squared from the models, the most informative levels of the hedgerow network structure, derived from the aerial photographs or SPOT-5 images, for explaining the abundance of carabid beetles were both the distance from the forest and the landscape grain at a scale of $250 \mathrm{~m}$. These models had the smallest AICc and the highest $r$-squared $\left(\mathrm{AICc}=115\right.$ and $\mathrm{r}^{2}$ adjusted $=0.55$ for SPOT -5 and $\mathrm{AICc}=116$ and $\mathrm{r}^{2}$ adjusted $=0.55$ for aerial photographs). We can thus conclude that the best explanatory variables were the same for these two types of remote sensing data. Indeed, all the explanatory variables derived from aerial photographs, SPOT-5 and TerraSAR-X images were highly correlated (Appendix B).

Secondly we evaluated the predictive power of the metrics derived from the TerraSAR-X image that best explained the spatial distribution of forest carabid beetles. These metrics characterize i) the hedgerow network structure (i.e. hedgerow density and landscape grain at 3 scales) and ii) the canopy cover (i.e. number of ShE pixels comprised between 0.5 and 5 highlighting areas with dense canopy cover at 3 scales). The best model shows that the abundance of carabid beetles is explained by the distance from the forest and the area of dense canopy cover at two scales: a local scale (i.e. $15 \mathrm{~m}$ ) and a landscape scale (i.e. $350 \mathrm{~m}$ ) (AICc= 91 and adjusted $r$-squared $=0.81$ ). The best models for TerraSAR-X, SPOT-5 and aerial photographs are presented in Appendix C. Models were considered different only if the AICc difference was greater than four (Burnham and Anderson, 2002).

The 'leave-one-out' method was thus applied to the final TerraSAR-X model (i.e. carabid abundance = "area of dense canopy cover at $15 \mathrm{~m}$ " + "area of dense canopy cover at $350 \mathrm{~m}$ " + "distance from the forest"). The results show a very high goodness-of-fit between the predicted values and the observed values ( $r$-squared $=0.8$ ) and a RMSE of 0.0006 (Figure 9). 


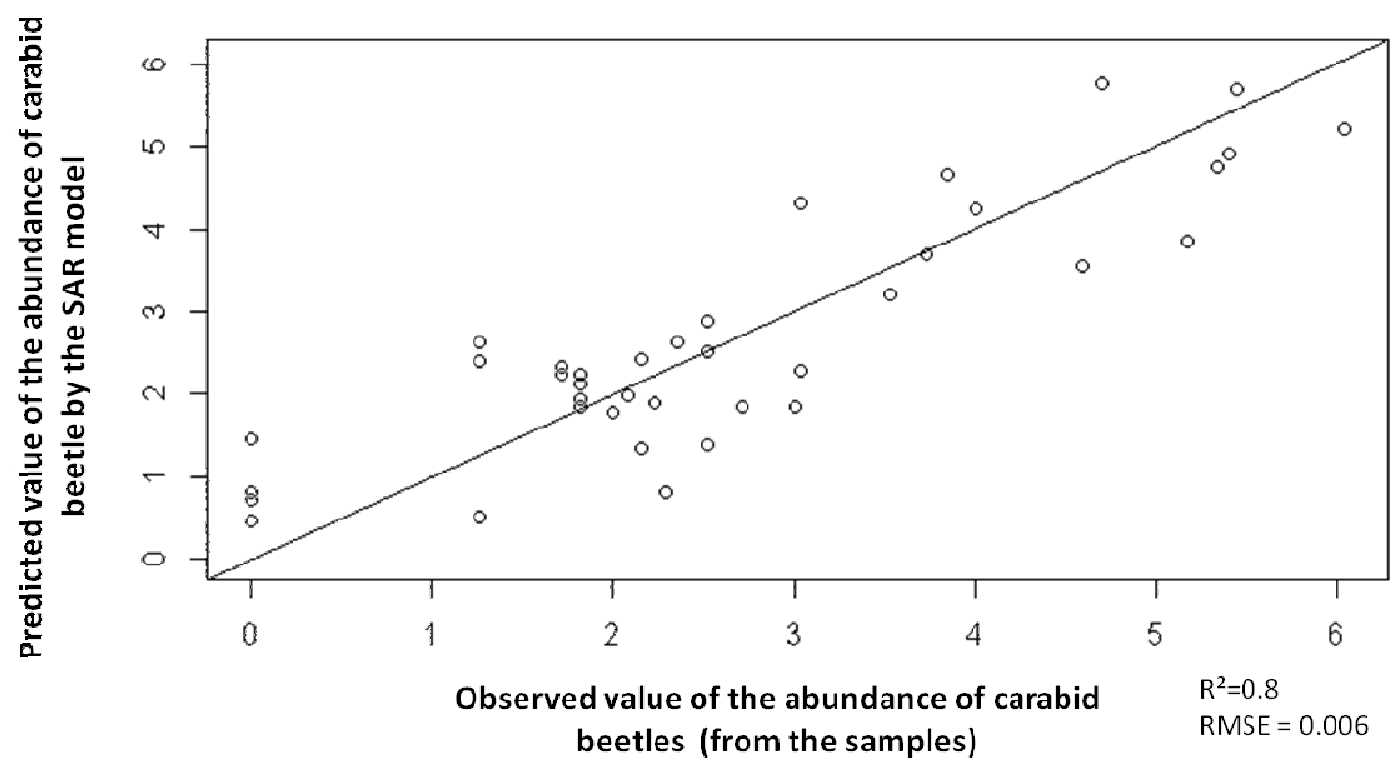

Figure 9. Result of the "leave-one out" method applied to the best TerraSAR-X model for carabid beetle abundance prediction

\section{Discussion}

Internal hedgerow structure is of utmost importance for many species only thriving in dense hedgerows. Charrier et al. (1997) show that the hedgerow vegetation density in agricultural landscapes is an important variable in order to explain forest species survival, and hedgerow quality influences its efficiency for species diffusion. In contrast, dense hedgerows can be a barrier for butterflies (Mauremooto et al., 1995). Burel (1987) shows that the internal hedgerow structure interacts with the corridor function of hedgerows to control the presence and abundance of forest carabid species. Hedgerows with only a few trees and almost bare soil do not harbor forest carabid beetles. This may be due to a source/sink effect e.g. woods acting as a continuous source of carabids for hedgerow networks. Nevertheless, most ecological studies rely on landscape structure to explain the spatial distribution of hedgerow species, leaving hedgerow structure out (Le Féon et al. 2013; Billeter et al, 2008). This could be mainly due to the difficulty in evaluating inner hedgerow structures from field observations. Therefore, it is very important to develop methods using remote sensing images such as TerraSAR-X radar images, which can be used to monitor hedgerow canopy cover and to detect gaps in hedgerow network structures (Betbeder et al. 2014b). Our approach, by 
analyzing the combination of satellite imagery and biological data, is a step forward in the use of remote sensing data for ecological applications, as advocated by Pettorelli et al. (2014). We established a strong correlation between hedgerow canopy cover and the abundance of forest carabid beetles at two scales: i.e. a local scale and a landscape scale. The originality of our approach lies in the fact that: 1) we used radar images for ecological applications and 2) we did not use an a priori segmentation of the map into classes, but looked for the best segmentation according to biological data. This implies that the segmentation may be different for another group of species. Radar images provide quantitative maps while almost all maps used in landscape ecology are categorical, therefore not suitable for the same segmentation process.

Concerning the extraction of the hedgerow network, this study confirms that radar and passive optical images can be used indifferently. The accuracy of the classification we applied to SPOT-5 and TerraSAR-X images using an object-oriented approach is high (percentage of correctly detected pixels $=92 \%$ for the optical image and $90 \%$ for the SAR image). These results are comparable to those from similar studies that aim to develop methods to automatically extract linear landscape features such as hedgerows from VHSR (Very High Spatial Resolution) optical data (Wiseman et al. 2009; Czerepowicz et al. 2012; Tansey et al. 2009) or VHSR radar data (Bargiel et al. 2013; Betbeder et al. 2014b). Therefore, the landscape metrics defined in order to characterize hedgerow network structure can be derived from classifications based on either image. Indeed, metrics derived from radar and passive optical images are highly correlated and provide similar information to explain the spatial distribution of forest carabid beetles.

However, hedgerow canopy cover cannot be assessed with passive optical remotely sensed data. Although many models have been developed to describe canopy structure using VISNIR imagery, varied vegetation types such as grasses, shrubs and trees reflect in a similar way and cannot be distinguished (Jacquemoud et al., 2009).

Among active remotely sensed data, LIDAR and radar data have already shown their potential to assess the internal tree structure (Kugler et al., 2014; Heinzel and Koch 2011; Popescu and Zhao 2008; Treuhaft and Siqueira, 2000). While information derived from LIDAR data has been successfully used to predict forest beetle assemblages in mountainous forests (Müller and Brandl 2009), the evaluation of information derived from SAR data has not been investigated until now. This study is the first, to our knowledge, to explore the potential of 
SAR images and more particularly of one polarimetric indicator (ShE) to explain the spatial distribution of carabid beetles. Indeed, Betbeder et al. (2014b) show a strong correlation between the Shannon entropy signal derived from TerraSAR-X imagery and hedgerow canopy cover assessed from the ground. This means that ShE can be used as a metric of hedgerow structure. In comparison to other remotely sensed data, in our case SPOT-5 and aerial photographs, the TerraSAR-X image has proven, in this study, its ability to improve models that aim to explain the spatial distribution of carabid beetles. The results show that areas with dense canopy cover (ShE values comprised between 0.5 and 5) at different scales is a strong predictor of the spatial distribution of carabid beetles in landscapes (adjusted rsquared $=0.81$ and RMSE $=0.006$ ). Indeed, this variable better explains the spatial distribution of the species ( $\mathrm{AICc}=87$ and $\mathrm{r}$-squared $=0.81$ ) than models only using hedgerow network structures e.g. "hedgerow density" or "landscape grain" (AICc=116 and rsquared $=0.55$ for the aerial photographs and $\mathrm{AICc}=115$ and $\mathrm{r}$-squared=0.55 for SPOT-5). The models using metrics derived from the SPOT-5 image and aerial photographs showed that the landscape grain at $250 \mathrm{~m}$ and the distance from the forest are the most significant variables. All these results on the effect of network structure are consistent with previous knowledge of the strong dependency of forest carabid beetles on dense vegetation (Vannier et al. 2011; Petit and Burel 1998). Hedgerow canopy cover and hedgerow network structures derived from SAR imagery explained the distribution of forest carabid beetles at local and landscape scales. The local scale (i.e. $15 \mathrm{~m}$ ) corresponds to favorable habitat of populations in hedgerows. It is close to the diameter of their home range in a hedgerow. The landscape scale (i.e. $350 \mathrm{~m}$ ) represents the distribution of "good quality" hedgerows in a landscape and could be the scale of meta-populations. It is also the scale of micro-climate regulation (Cleugh and Hughes 2002). These results are consistent with the theory that states that processes at multiple scales drive biodiversity (Levin, 1992). A noticeable result is that the optimum ShE value is the same for all scales of analysis, from a $15 \mathrm{~m}$ segment of hedgerow to a 12.25 ha area of landscape encompassing several hedgerows. This confirms that both the habitat structure and the landscape structure controlling the microclimate have synergistic effects.

In all models, we note that the 'distance from the forest' variable is also important in explaining the carabid beetle distribution. This result is in accordance with previous studies that showed that distance from the forest is an important ecological variable in explaining the spatial distribution of carabid beetles (Burel 1989). 
Our results open new avenues for a better understanding of the role of hedgerow and network structures and dynamics as drivers of biodiversity. Species distribution is more often driven by the spatio-temporal structure rather than the landscape structure at a given time (Burel, 1993). SAR images can be used to monitor the spatio-temporal dynamics of hedgerow network structures. This would be useful to address questions on extinction or colonization debts, i.e. the fact that landscapes and species distributions do not change at the same rate (Vellend et al., 2006).

In rural areas, ecological processes are increasingly taken into consideration in public policies and landscape management, especially for the maintenance or restoration of ecosystem services (Lant et al. 2008). For instance ecological networks are part of most planning schemes (Opdam et al. 2006). Hedgerow networks are often a reference in these schemes. Hedgerow structures are mainly determined by agricultural practices (Lotfi et al., 2010). Radar imagery could guide planners in land planning, by identifying hedgerows with a dense and complex vegetation structure that should be preserved in order to enhance the survival of forest carabid beetles (Charrier et al. 1997). Moreover, this kind of quantitative data set could help ecological scientists to establish their species sampling, i.e. in order to control certain structural hedgerow variables without performing time-consuming field inventories. Hedgerow structure derived from TerraSAR-X images could also help hydrological scientists in studying the role of hedgerows as a trap for nitrates, as more trees means more water with its nutrients absorbed.

For further work it would be interesting to study what is the "functional" value of the Shannon entropy that best explains the distribution of other species such as birds (Arnold 1983; Hinsley and Bellamy 2000) or micro-mammals (Michel et al., 2007). It would also be interesting to take into account the phenology of surrounding crops and the agricultural practices applied to hedgerows, such as the use of pesticides, to improve the model developed in this study (Aude et al., 2004).

Several authors have pointed out that the spatial scales provided by remote sensing systems and those used in ecological studies do not match (Turner et al. 2003; Kerr and Ostrovsky 2003). This paper is an example of how interdisciplinarity between remote sensing and landscape ecology can enhance our understanding of ecological patterns. Upcoming sensors, such as Sentinel 1 and Sentinel 2, will have new properties in order to study other aspects of land cover and land use which could be very useful in many ecological applications. Sentinel 
1 and Sentinel 2 (respectively SAR and optical sensor) will be able to acquire high spatial and temporal (5 day revisit time) resolution images and thus will be able to precisely monitor vegetation phenology.

\section{Conclusion}

The purpose of this paper was not to obtain better knowledge of the ecology of forest carabids, but to test the ability of different remote sensing data to monitor the state of vegetation structure and organization at multiples scales. This complements the work by Vannier et al (2011) in which the relationships between optical images at different spatial resolutions and carabid distribution were tested. Here, we tested metrics which are inaccessible using ground-based methods alone. VHSR SAR images provide new data to characterize vegetation structure and more particularly hedgerow canopy cover, a variable known to explain the spatial distribution of carabid beetles in an agricultural landscape, but not yet quantified at a fine scale. Thus, this study shows the high potential of remotely sensed data for modeling biodiversity in hedgerow network landscapes at a broad scale. SAR images provide interesting information about vegetation structure and spatial distribution that could enable biologists and ecologists to evaluate habitats over large areas in order to understand species distribution and thus to understand and characterize their environment. It opens new avenues for further tests with other groups of species to address two main questions: 1) how different are the optima for the different groups and, 2) for a given group, are the optima similar at all scales.

\section{Acknowledgments}

This work was supported by the DIVA 3- AGRICONNECT program, the CNES (PhD grant to J. Betbeder), the DLR by providing TerraSAR-X imagery, and the Zone Atelier Armorique. We thank Jean-Luc Roger and Quentin Landais for field assistance, Rémi Duflot for his help in statistics, and Eric Pottier for his helpful comments on radar processing. 


\section{References}

Aksoy, S., Akcay, G., Cinbis, G., Wassenaar, T., 2008. Automatic Mapping of Linearwoody Vegetation Features in Agricultural Landscapes, in: Geoscience and Remote Sensing Symposium, 2008. IGARSS 2008. IEEE International. Presented at the Geoscience and Remote Sensing Symposium, 2008. IGARSS 2008. IEEE International, pp. IV 403-IV - 406. doi:10.1109/IGARSS.2008.4779743

Arnold, G.W., 1983. The influence of ditch and hedgerow structure, length of hedgerows, and area of woodland and garden on bird numbers on farmland. J. Appl. Ecol. 20, 731750.

Aude, E., Tybirk, K., Michelsen, A., Ejrnæs, R., Hald, A.B., Mark, S., 2004. Conservation value of the herbaceous vegetation in hedgerows - does organic farming make a difference? Biol. Conserv. 118, 467-478. doi:10.1016/j.biocon.2003.09.022

Aviron, S., Burel, F., Baudry, J., Schermann, N., 2005. Carabid assemblages in agricultural landscapes: impacts of habitat features, landscape context at different spatial scales and farming intensity. Agric. Ecosyst. Environ. 108, 205-217. doi:10.1016/j.agee.2005.02.004

Bargiel, D., 2013. Capabilities of high resolution satellite radar for the detection of seminatural habitat structures and grasslands in agricultural landscapes. Ecol. Inform. 13, 9-16. doi:10.1016/j.ecoinf.2012.10.004

Baudry, J., Bunce, R.G.., Burel, F., 2000. Hedgerows: An international perspective on their origin, function and management. J. Environ. Manage. 60, 7-22. doi:10.1006/jema.2000.0358

Baudry, J., Burel, F., Thenail, C., Le Cœur, D., 2000. A holistic landscape ecological study of the interactions between farming activities and ecological patterns in Brittany, France. Landsc. Urban Plan. 50, 119-128. doi:10.1016/S0169-2046(00)00084-0

Baudry, J., Jouin, A., Institut national de la recherche agronomique (France), 2003. De la haie aux bocages organisation, dynamique et gestion. Institut national de la recherche agronomique, Paris.

Benz, U.C., Hofmann, P., Willhauck, G., Lingenfelder, I., Heynen, M., 2004. Multiresolution, object-oriented fuzzy analysis of remote sensing data for GIS-ready information. ISPRS J. Photogramm. Remote Sens. 58, 239-258. doi:10.1016/j.isprsjprs.2003.10.002

Betbeder, J., Rapinel, S., Corpetti, T., Pottier, E., Corgne, S., Hubert-Moy, L., 2014a. Multitemporal classification of TerraSAR-X data for wetland vegetation mapping. J. Appl. Remote Sens. 8, 083648-083648. doi:10.1117/1.JRS.8.083648

Betbeder, J., Nabucet, J., Pottier, E., Baudry, J., Corgne, S., Hubert-Moy, L., 2014b. Detection and Characterization of Hedgerows Using TerraSAR-X Imagery. Remote Sens. 6, 3752-3769. doi:10.3390/rs6053752

Blaschke, T., Strobl, J., 2001. What's wrong with pixels? Some recents developments interfacing remote sensing and gis. GeoBIT/GIS 6, 12-17.

Burel, F., 1989a. Landscape structure effects on carabid beetles spatial patterns in western France. Landsc. Ecol. 2, 215-226. doi:10.1007/BF00125092

Burel, F., 1989b. Landscape structure effects on carabid beetles spatial patterns in western France. Landsc. Ecol. 2, 215-226. doi:10.1007/BF00125092

Burel, F., Baudry, J., 1990. Structural dynamic of a hedgerow network landscape in Brittany France. Landsc. Ecol. 4, 197-210. doi:10.1007/BF00129828

Burnham, K.P., Anderson, D.R., 2002. Model Selection and Multimodel Inference: A Practical Information-Theoretic Approach. Springer. 
Burnham, K.P., Anderson, D.R., Huyvaert, K.P., 2011. AIC model selection and multimodel inference in behavioral ecology: some background, observations, and comparisons. Behav. Ecol. Sociobiol. 65, 23-35. doi:10.1007/s00265-010-1029-6

Charrier, S., Petit, S., Burel, F., 1997. Movements of Abax parallelepipedus (Coleoptera, Carabidae) in woody habitats of a hedgerow network landscape: a radio-tracing study. Agric. Ecosyst. Environ. 61, 133-144. doi:10.1016/S0167-8809(96)01101-2

Clark, M.L., Roberts, D.A., Clark, D.B., 2005. Hyperspectral discrimination of tropical rain forest tree species at leaf to crown scales. Remote Sens. Environ. 96, 375-398. doi:10.1016/j.rse.2005.03.009

Cleugh, H.A., Hughes, D.E., 2002. Impact of shelter on crop microclimates: a synthesis of results from wind tunnel and field experiments. Aust. J. Exp. Agric. 42, 679-701.

Czerepowicz, L., Case, B.S., Doscher, C., 2012. Using satellite image data to estimate aboveground shelterbelt carbon stocks across an agricultural landscape. Agric. Ecosyst. Environ. 156, 142-150. doi:10.1016/j.agee.2012.05.014

Defra, 2007. Hedgerow Survey Handbook. A standard procedure for local surveys in the UK., Defra. ed. London.

Forman, R.T.T., Baudry, J., 1984. Hedgerows and hedgerow networks in landscape ecology. Environ. Manage. 8, 495-510. doi:10.1007/BF01871575

Hastier, T., Tibshirani, R., Friedman, J., 2009. The Elements of Statistical Learning - Data Mining, Inference, and Prediction, Second Edition, 2nd edition. ed. Springer series in statistics.

Heinzel, J., Koch, B., 2011. Exploring full-waveform LiDAR parameters for tree species classification. Int. J. Appl. Earth Obs. Geoinformation 13, 152-160. doi:10.1016/j.jag.2010.09.010

Hinsley, S.., Bellamy, P.., 2000. The influence of hedge structure, management and landscape context on the value of hedgerows to birds: A review. J. Environ. Manage. 60, 33-49. doi:10.1006/jema.2000.0360

Imhoff, M.L., Sisk, T.D., Milne, A., Morgan, G., Orr, T., 1997. Remotely sensed indicators of habitat heterogeneity: Use of synthetic aperture radar in mapping vegetation structure and bird habitat. Remote Sens. Environ. 60, 217-227. doi:10.1016/S00344257(96)00116-2

Jacquemoud, S., Verhoef, W., Baret, F., Bacour, C., Zarco-Tejada, P.J., Asner, G.P., François, C., Ustin, S.L., 2009. PROSPECT + SAIL models: A review of use for vegetation characterization. Remote Sens. Environ. 113, Supplement 1, S56-S66. doi:10.1016/j.rse.2008.01.026

Kasischke, E.S., Melack, J.M., Dobson, M.C., 1997. The use of imaging radars for ecological applications-A review. Remote Sensing of Environment 59, 2, 141-156.

Kerr, J.T., Ostrovsky, M., 2003. From space to species: ecological applications for remote sensing. Trends Ecol. Amp Evol. 18, 299-305.

Kromp, B., 1999. Carabid beetles in sustainable agriculture: a review on pest control efficacy, cultivation impacts and enhancement. Agric. Ecosyst. Environ. 74, 187-228. doi:10.1016/S0167-8809(99)00037-7

Kugler, F., D. Schulze, I Hajnsek, H. Pretzsch, et K.P. Papathanassiou. 2014. « TanDEM-X Pol-InSAR Performance for Forest Height Estimation». IEEE Transactions on Geoscience and Remote Sensing 52 (10): 6404-22. doi:10.1109/TGRS.2013.2296533.

Lant, C.L., Ruhl, J.B., Kraft, S.E., 2008. The Tragedy of Ecosystem Services. BioScience 58, 969-974. doi:10.1641/B581010

Le Cœur, D., Baudry, J., Burel, F., Thenail, C., 2002. Why and how we should study field boundary biodiversity in an agrarian landscape context. Agric. Ecosyst. Environ., The 
Ecology of Field Margins in European Farming Systems 89, 23-40. doi:10.1016/S0167-8809(01)00316-4

Le Féon, V., Burel, F., Chifflet, R., Henry, M., Ricroch, A., Vaissière, B.E., Baudry, J., 2013. Solitary bee abundance and species richness in dynamic agricultural landscapes. Agric. Ecosyst. Environ., Landscape ecology and biodiversity in agricultural landscapes 166, 94-101. doi:10.1016/j.agee.2011.06.020

Lee, J.-S., 1981. Speckle analysis and smoothing of synthetic aperture radar images. Comput. Graph. Image Process. 17, 24-32. doi:10.1016/S0146-664X(81)80005-6

Lee, J.-S., Pottier, E., 2009. Polarimetric Radar Imaging: From Basics to Applications. CRC Press.

Legendre, P., Legendre, L., 2012. Numerical Ecology. Elsevier.

Levanoni, O., Levin, N., Pe'er, G., Turbé, A., Kark, S., 2011. Can we predict butterfly diversity along an elevation gradient from space? Ecography 34, 372-383. doi:10.1111/j.1600-0587.2010.06460.x

Levin, S.A., 1992. The Problem of Pattern and Scale in Ecology: The Robert H. MacArthur Award Lecture. Ecology 73, 1943-1967. doi:10.2307/1941447

Loreau, M., Nolf, C.-L., 1993. Occupation of space by the carabid beetle Abax ater. Acta Oecologica 14, 247-258.

Lotfi, A., Javelle, A., Baudry, J., Burel, F., 2010. Interdisciplinary Analysis of Hedgerow Network Landscapes' Sustainability. Landsc. Res. 35, 415-426. doi:10.1080/01426397.2010.486857

Mauremooto, J.R., Wratten, S.D., Worner, S.P., Fry, G.L.A., 1995. Permeability of hedgerows to predatory carabid beetles. Agric. Ecosyst. Environ. 52, 141-148. doi:10.1016/0167-8809(94)00548-S

Michel, N., Burel, F., Legendre, P., Butet, A., 2007. Role of habitat and landscape in structuring small mammal assemblages in hedgerow networks of contrasted farming landscapes in Brittany, France. Landsc. Ecol. 22, 1241-1253. doi:10.1007/s10980007-9103-9

Müller, J., Brandl, R., 2009. Assessing biodiversity by remote sensing in mountainous terrain: the potential of LiDAR to predict forest beetle assemblages. J. Appl. Ecol. 46, 897905. doi:10.1111/j.1365-2664.2009.01677.x

Opdam, P., Steingröver, E., Rooij, S. van, 2006. Ecological networks: A spatial concept for multi-actor planning of sustainable landscapes. Landsc. Urban Plan., Landscapes and sustainability 75, 322-332. doi:10.1016/j.landurbplan.2005.02.015

Pearson, D.L., 1994. Selecting indicator taxa for the quantitative assessment of biodiversity. Philos. Trans. R. Soc. Lond. B. Biol. Sci. 345, 75-79. doi:10.1098/rstb.1994.0088

Petit, S., Burel, F., 1998. Effects of landscape dynamics on the metapopulation of a ground beetle (Coleoptera, Carabidae) in a hedgerow network. Agric. Ecosyst. Environ. 69, 243-252. doi:10.1016/S0167-8809(98)00111-X

Pettorelli, N., Laurance, W.F., O’Brien, T.G., Wegmann, M., Nagendra, H., Turner, W., 2014. Satellite remote sensing for applied ecologists: opportunities and challenges. J. Appl. Ecol. n/a-n/a. doi:10.1111/1365-2664.12261

Pettorelli, N., Vik, J.O., Mysterud, A., Gaillard, J.-M., Tucker, C.J., Stenseth, N.C., 2005. Using the satellite-derived NDVI to assess ecological responses to environmental change. Trends Ecol. Evol. 20, 503-510. doi:10.1016/j.tree.2005.05.011

Popescu, S.C., Zhao, K., 2008. A voxel-based lidar method for estimating crown base height for deciduous and pine trees. Remote Sens. Environ. 112, 767-781. doi:10.1016/j.rse.2007.06.011

Pottier, E., Ferro-Famil, L., 2012. PolSARPro V5.0: An ESA educational toolbox used for self-education in the field of POLSAR and POL-INSAR data analysis, in: Geoscience 
and Remote Sensing Symposium (IGARSS), 2012 IEEE International. Presented at the Geoscience and Remote Sensing Symposium (IGARSS), 2012 IEEE International, pp. 7377-7380. doi:10.1109/IGARSS.2012.6351925

$\mathrm{Pu}, \mathrm{R} ., 2$ 2009. Broadleaf species recognition with in situ hyperspectral data. Int. J. Remote Sens. 30, 2759-2779. doi:10.1080/01431160802555820

St-Louis, V., Pidgeon, A.M., Clayton, M.K., Locke, B.A., Bash, D., Radeloff, V.C., 2009. Satellite image texture and a vegetation index predict avian biodiversity in the Chihuahuan Desert of New Mexico. Ecography 32, 468-480. doi:10.1111/j.16000587.2008.05512.x

Tanré, D., Deroo, C., Duhaut, P., Herman, M., Morcrette, J.J., Perbos, J., Deschamps, P.Y., 1990. Technical note Description of a computer code to simulate the satellite signal in the solar spectrum: the $5 \mathrm{~S}$ code. Int. J. Remote Sens. 11, 659-668. doi:10.1080/01431169008955048

Tansey, K., Chambers, I., Anstee, A., Denniss, A., Lamb, A., 2009. Object-oriented classification of very high resolution airborne imagery for the extraction of hedgerows and field margin cover in agricultural areas. Appl. Geogr. 29, 145-157. doi:10.1016/j.apgeog.2008.08.004

Thiele, H.U., 1977. Carabid beetles in their environments. A study on habitat selection by adaptation in physiology and behaviour. xvii +369 pp.

Tucker, C.J., 1979. Red and photographic infrared linear combinations for monitoring vegetation. Remote Sens. Environ. 8, 127-150. doi:10.1016/0034-4257(79)90013-0

Turner, W., Spector, S., Gardiner, N., Fladeland, M., Sterling, E., Steininger, M., 2003. Remote sensing for biodiversity science and conservation. Trends Ecol. Evol. 18, 306314. doi:10.1016/S0169-5347(03)00070-3

Treuhaft, R.N, et P.R Siqueira. 2000. «Vertical structure of vegetated land surfaces from interferometric and polarimetric radar ». Radio Science 35 (1): 141-77.

Ulaby, F.T., 1990. Radar polarimetry for geoscience applications. Artech House.

Vannier, C., Hubert-Moy, L., 2010. Wooded hedgerows characterization in rural landscape using very high spatial resolution satellite images, in: Geoscience and Remote Sensing Symposium (IGARSS), 2010 IEEE International. Presented at the Geoscience and Remote Sensing Symposium (IGARSS), 2010 IEEE International, pp. 347-350. doi:10.1109/IGARSS.2010.5651636

Vannier, C., Vasseur, C., Hubert-Moy, L., Baudry, J., 2011. Multiscale ecological assessment of remote sensing images. Landsc. Ecol. 26, 1053-1069. doi:10.1007/s10980-0119626-y

Vellend, M., Verheyen, K., Jacquemyn, H., Kolb, A., Van Calster, H., Peterken, G., Hermy, M., 2006. Extinction debt of forest plants persists for more than a century following habitat fragmentation. Ecology 87, 542-548. doi:10.1890/05-1182

Wiseman, G., Kort, J., Walker, D., 2009. Quantification of shelterbelt characteristics using high-resolution imagery. Agric. Ecosyst. Environ. 131, 111-117. doi:10.1016/j.agee.2008.10.018 
APPENDIX A. Correlation matrix of the landscape metrics derived from the aerial photographs (A-

P), SPOT-5 and TerraSAR-X (TSX) at multiple scales used in the different models. Values are coefficients of determination $\left(\mathrm{r}^{2}\right)$. $\mathrm{HD}=$ hedgerow density; $\mathrm{LG}=$ landscape grain, $\mathrm{CS}=$ canopy structure

\begin{tabular}{|c|c|c|c|c|c|c|}
\hline & \multicolumn{6}{|c|}{$\begin{array}{l}\text { Aerial Photograph } \\
\end{array}$} \\
\hline & $\begin{array}{l}\text { HD A-P } \\
(150 \mathrm{~m})\end{array}$ & $\begin{array}{l}\text { HD A-P } \\
(250 \mathrm{~m})\end{array}$ & $\begin{array}{l}\text { HD A-P } \\
(350 \mathrm{~m})\end{array}$ & $\begin{array}{l}\text { LG A-P } \\
(150 \mathrm{~m})\end{array}$ & $\begin{array}{l}\text { LG A-P } \\
(250 \mathrm{~m})\end{array}$ & $\begin{array}{l}\text { LG A-P } \\
(350 \mathrm{~m})\end{array}$ \\
\hline $\begin{array}{l}\text { HD A-P } \\
(150 \mathrm{~m})\end{array}$ & 1 & 0.65 & 0.65 & 0.25 & 0.3 & 0.3 \\
\hline $\begin{array}{l}\text { HD A-P } \\
(250 \mathrm{~m})\end{array}$ & & 1 & 0.65 & 0.3 & 0.4 & 0.45 \\
\hline $\begin{array}{l}\text { HD A-P } \\
(350 \mathrm{~m})\end{array}$ & & & 1 & 0.3 & 0.4 & 0.5 \\
\hline $\begin{array}{l}\text { LG A-P } \\
(150 \mathrm{~m})\end{array}$ & & & & 1 & 0.6 & 0.45 \\
\hline $\begin{array}{l}\text { LG A-P } \\
(250 \mathrm{~m})\end{array}$ & & & & & 1 & 0.6 \\
\hline \multirow[t]{3}{*}{$\begin{array}{l}\text { LG A-P } \\
(350 \mathrm{~m})\end{array}$} & & & & & & 1 \\
\hline & \multicolumn{6}{|c|}{ SPOT-5 } \\
\hline & $\begin{array}{l}\text { HD SPOT-5 } \\
(150 \mathrm{~m})\end{array}$ & $\begin{array}{l}\text { HD SPOT-5 } \\
(250 \mathrm{~m})\end{array}$ & $\begin{array}{l}\text { HD SPOT-5 } \\
(350 \mathrm{~m})\end{array}$ & $\begin{array}{l}\text { LG SPOT-5 } \\
(150 \mathrm{~m})\end{array}$ & $\begin{array}{l}\text { LG SPOT-5 } \\
(250 \mathrm{~m})\end{array}$ & $\begin{array}{l}\text { LG SPOT-5 } \\
(350 \mathrm{~m})\end{array}$ \\
\hline $\begin{array}{l}\text { HD SPOT-5 } \\
(150 \mathrm{~m})\end{array}$ & 1 & 0.65 & 0.6 & 0.4 & 0.5 & 0.3 \\
\hline $\begin{array}{l}\text { HD SPOT-5 } \\
(250 \mathrm{~m})\end{array}$ & & 1 & 0.6 & 0.3 & 0.4 & 0.4 \\
\hline $\begin{array}{l}\text { HD SPOT-5 } \\
(350 \mathrm{~m})\end{array}$ & & & 1 & 0.3 & 0.4 & 0.45 \\
\hline $\begin{array}{l}\text { LG SPOT-5 } \\
(150 \mathrm{~m})\end{array}$ & & & & 1 & 0.6 & 0.4 \\
\hline $\begin{array}{l}\text { LG SPOT-5 } \\
(250 \mathrm{~m})\end{array}$ & & & & & 1 & 0.6 \\
\hline $\begin{array}{l}\text { LG SPOT-5 } \\
(350 \mathrm{~m})\end{array}$ & & & & & & 1 \\
\hline
\end{tabular}




\begin{tabular}{|c|c|c|c|c|c|c|c|c|c|c|c|}
\hline & \multicolumn{11}{|c|}{ TerraSAR-X } \\
\hline & $\begin{array}{l}\text { HD } \\
\text { TSX } \\
(150 \mathrm{~m})\end{array}$ & $\begin{array}{l}\text { HD } \\
\text { TSX } \\
(250 \\
\text { m) }\end{array}$ & $\begin{array}{l}\text { HD } \\
\text { TSX } \\
(350 \\
\text { m) }\end{array}$ & $\begin{array}{l}\text { LG } \\
\text { TSX } \\
(150 \\
\text { m) }\end{array}$ & \begin{tabular}{|l|} 
LG \\
TSX \\
$(250$ \\
m) \\
\end{tabular} & \begin{tabular}{|l|} 
LG \\
TSX \\
$(350$ \\
m)
\end{tabular} & \begin{tabular}{|l|} 
CS \\
TSX \\
$(15$ \\
m)
\end{tabular} & $\begin{array}{l}\text { CS } \\
\text { TSX } \\
(\mathbf{5 0} \\
\text { m) }\end{array}$ & $\begin{array}{l}\text { CS } \\
\text { TSX } \\
(150 \\
\text { m) }\end{array}$ & $\begin{array}{l}\text { CS } \\
\text { TSX } \\
(250 \\
\text { m) }\end{array}$ & $\begin{array}{l}\text { CS } \\
\text { TSX } \\
(\mathbf{3 5 0} \\
\text { m) }\end{array}$ \\
\hline $\begin{array}{l}\text { HD } \\
\text { TSX } \\
(150 \mathrm{~m})\end{array}$ & 1 & 065 & 0.6 & NS & NS & NS & NS & 0.3 & 0.4 & 0.4 & 0.35 \\
\hline $\begin{array}{l}\text { HD } \\
\text { TSX } \\
(250 \mathrm{~m})\end{array}$ & & 1 & 0.6 & 0.4 & 0.3 & 0.3 & NS & 0.3 & 0.4 & 0.5 & 0.45 \\
\hline $\begin{array}{l}\text { HD } \\
\text { TSX } \\
(350 \mathrm{~m})\end{array}$ & & & 1 & NS & NS & NS & NS & 0.3 & 0.5 & 0.5 & 0.5 \\
\hline $\begin{array}{l}\text { LG } \\
\text { TSX } \\
\text { (150 m) }\end{array}$ & & & & 1 & 0.5 & 0.3 & NS & NS & NS & NS & NS \\
\hline $\begin{array}{l}\text { LG } \\
\text { TSX } \\
(250 \mathrm{~m})\end{array}$ & & & & & 1 & 0.6 & NS & NS & NS & NS & NS \\
\hline $\begin{array}{l}\text { LG } \\
\text { TSX } \\
(350 \mathrm{~m})\end{array}$ & & & & & & 1 & NS & NS & NS & NS & NS \\
\hline $\begin{array}{l}\text { CS } \\
\text { TSX } \\
(15 \mathrm{~m})\end{array}$ & & & & & & & 1 & NS & NS & NS & NS \\
\hline $\begin{array}{l}\text { CS } \\
\text { TSX } \\
(50 \mathrm{~m})\end{array}$ & & & & & & & & 1 & 0.4 & 0.3 & 0.4 \\
\hline $\begin{array}{l}\text { CS } \\
\text { TSX } \\
(150 \mathrm{~m})\end{array}$ & & & & & & & & & 1 & 0.6 & .0 .5 \\
\hline $\begin{array}{l}\text { CS } \\
\text { TSX } \\
(250 \mathrm{~m})\end{array}$ & & & & & & & & & & 1 & 0.65 \\
\hline $\begin{array}{l}\text { CS } \\
\text { TSX } \\
(350 \mathrm{~m})\end{array}$ & & & & & & & & & & & 1 \\
\hline
\end{tabular}


APPENDIX B. Correlation matrix of the landscape metrics derived from the aerial photographs (AP), SPOT-5 and TerraSAR-X (TSX) at multiple scales. Values are coefficients of determination $\left(\mathrm{r}^{2}\right)$.

\begin{tabular}{|c|c|c|c|c|c|c|}
\hline \multirow[t]{2}{*}{$\mathbf{R}^{2}$} & \multicolumn{6}{|c|}{ Scale $=150 \mathrm{~m}$} \\
\hline & HD A-P & $\begin{array}{c}\text { HD SPOT- } \\
5\end{array}$ & HD TSX & LG A-P & LG SPOT-5 & LG TSX \\
\hline $\begin{array}{l}\text { HD } 150 \mathrm{~m} \\
\text { A-P }\end{array}$ & 1 & 0.55 & 0.52 & & & \\
\hline $\begin{array}{l}\text { HD } 150 \mathrm{~m} \\
\text { SPOT-5 }\end{array}$ & & 1 & 0.8 & & & \\
\hline $\begin{array}{l}\text { LG } 150 \mathrm{~m} \\
\text { Ortho }\end{array}$ & & & & 1 & 0.8 & 0.6 \\
\hline \multirow[t]{3}{*}{$\begin{array}{l}\text { LG } 150 \text { m } \\
\text { SPOT-5 } \\
\end{array}$} & & & & & 1 & 0.67 \\
\hline & \multicolumn{6}{|c|}{ Scale $=250 \mathrm{~m}$} \\
\hline & HD A-P & $\begin{array}{c}\text { HD SPOT- } \\
5\end{array}$ & HD TSX & LG A-P & LG SPOT-5 & LG TSX \\
\hline $\begin{array}{l}\text { HD } 250 \mathrm{~m} \\
\text { A-P }\end{array}$ & 1 & 0.73 & 0.69 & & & \\
\hline $\begin{array}{l}\text { HD } 250 \mathrm{~m} \\
\text { SPOT-5 }\end{array}$ & & 1 & 0.95 & & & \\
\hline $\begin{array}{l}\text { LG } 250 \mathrm{~m} \\
\text { A-P }\end{array}$ & & & & 1 & 0.5 & 0.55 \\
\hline \multirow[t]{3}{*}{$\begin{array}{l}\text { LG 250 m } \\
\text { SPOT-5 }\end{array}$} & & & & & 1 & 0.6 \\
\hline & \multicolumn{6}{|c|}{ Scale $=350 \mathrm{~m}$} \\
\hline & HD A-P & $\begin{array}{c}\text { HD SPOT- } \\
5\end{array}$ & HD TSX & LG A-P & LG SPOT-5 & LG TSX \\
\hline $\begin{array}{l}\text { HD } 350 \mathrm{~m} \\
\text { A-P }\end{array}$ & 1 & 0.55 & 0.50 & & & \\
\hline $\begin{array}{l}\text { HD } 350 \mathrm{~m} \\
\text { SPOT-5 }\end{array}$ & & 1 & 0.90 & & & \\
\hline $\begin{array}{l}\text { LG } 350 \mathrm{~m} \\
\text { A-P }\end{array}$ & & & & 1 & 0.45 & 0.4 \\
\hline $\begin{array}{l}\text { LG } 350 \mathrm{~m} \\
\text { SPOT-5 }\end{array}$ & & & & & 1 & 0.6 \\
\hline
\end{tabular}


APPENDIX C. Best models establishing relationships between the abundance of forest carabid beetles and the metrics derived from TerraSAR$\mathrm{X}$ (TSX); Aerial photographs (A-P) and SPOT-5 image. Best models were selected using the AICc and adjusted r-squared. HD = hedgerow density; $L G$ = landscape Grain, $C S$ = canopy structure

\begin{tabular}{|c|c|c|c|c|c|c|c|c|c|c|c|c|c|c|}
\hline & $\begin{array}{l}\text { HD } \\
\text { TSX } \\
(150 \text { m) }\end{array}$ & $\begin{array}{l}\text { HD } \\
\text { TSX } \\
(250 \mathrm{~m})\end{array}$ & $\begin{array}{l}\text { HD } \\
\text { TSX } \\
(350 \text { m) }\end{array}$ & $\begin{array}{l}\text { LG } \\
\text { TSX } \\
(150 \text { m) }\end{array}$ & $\begin{array}{l}\text { LG } \\
\text { TSX } \\
(250 \text { m) }\end{array}$ & $\begin{array}{l}\text { LG } \\
\text { TSX } \\
(\mathbf{3 5 0} \mathbf{~ m})\end{array}$ & FD & $\begin{array}{l}\text { CS TSX } \\
(15 \mathrm{~m})\end{array}$ & $\begin{array}{l}\text { CS TSX } \\
(50 \mathrm{~m})\end{array}$ & $\begin{array}{l}\text { CS TSX } \\
(150 \mathrm{~m})\end{array}$ & $\begin{array}{l}\text { CS TSX } \\
(250 \mathrm{~m})\end{array}$ & $\begin{array}{l}\text { CS TSX } \\
\text { (350 m) }\end{array}$ & AICc & r-adjusted \\
\hline Abundance & & & & & & & $\mathrm{X}$ & $\mathrm{X}$ & & & $\mathrm{X}$ & & 91 & 0.81 \\
\hline Abundance & & & & & $\mathrm{X}$ & & $\mathrm{X}$ & $x$ & & & $\mathrm{X}$ & & 93.4 & 0.79 \\
\hline Abundance & & & & & & & $x$ & $x$ & $x$ & & $x$ & & 93.6 & 0.78 \\
\hline Abundance & & & & & & & $x$ & $x$ & $x$ & $x$ & & & 93.7 & 0.76 \\
\hline Abundance & & & & $x$ & & & $x$ & $x$ & & & $\mathrm{X}$ & & 93.7 & 0.76 \\
\hline Abundance & & & & & & $\mathrm{x}$ & $x$ & $x$ & & & $x$ & & 93.9 & 0.78 \\
\hline Abundance & $x$ & & & & & & $X$ & $x$ & & & $x$ & & 94.0 & 0.78 \\
\hline Abundance & & $x$ & & & & & $x$ & $x$ & & & $x$ & & 94.1 & 0.78 \\
\hline Abundance & & & $\mathrm{x}$ & & & & $\mathrm{X}$ & $\mathrm{X}$ & & & $\mathrm{X}$ & & 94.1 & 0.78 \\
\hline Abundance & & & & $\mathrm{X}$ & & $\mathrm{X}$ & $\mathrm{X}$ & $\mathrm{X}$ & & & $x$ & & 94.9 & 0.79 \\
\hline
\end{tabular}

\begin{tabular}{|l|l|l|l|l|l|l|l|l|l|}
\hline & $\begin{array}{l}\text { HD A-P } \\
(\mathbf{1 5 0} \mathbf{~ m})\end{array}$ & $\begin{array}{l}\text { HD A-P } \\
(\mathbf{2 5 0} \mathbf{~ m})\end{array}$ & $\begin{array}{l}\text { HD A-P } \\
(\mathbf{3 5 0} \mathbf{~ m})\end{array}$ & $\begin{array}{l}\text { LG A-P } \\
(\mathbf{1 5 0} \mathbf{~ m})\end{array}$ & $\begin{array}{l}\text { LG A-P } \\
(\mathbf{2 5 0} \mathbf{~ m})\end{array}$ & $\begin{array}{l}\text { LG A-P } \\
\mathbf{( 3 5 0} \mathbf{~ m})\end{array}$ & FD & AICc & r-adjusted \\
\hline Abundance & & $\mathrm{X}$ & & & & & $\mathrm{X}$ & 116.2 & 0.56 \\
\hline Abundance & & $\mathrm{X}$ & $\mathrm{X}$ & & & & $\mathrm{X}$ & 118.1 & 0.55 \\
\hline Abundance & & $\mathrm{X}$ & & & $\mathrm{X}$ & & $\mathrm{X}$ & 118.2 & 0.55 \\
\hline Abundance & & $\mathrm{X}$ & & & & & $\mathrm{X}$ & 118.5 & 0.54 \\
\hline Abundance & & $\mathrm{X}$ & & $\mathrm{X}$ & & & $\mathrm{X}$ & 118.6 & 0.54 \\
\hline Abundance & & $\mathrm{X}$ & & & & $\mathrm{X}$ & $\mathrm{X}$ & 118.7 & 0.55 \\
\hline Abundance & & $\mathrm{X}$ & & & $\mathrm{X}$ & $\mathrm{X}$ & $\mathrm{X}$ & 120.1 & 0.55 \\
\hline
\end{tabular}




\begin{tabular}{|c|c|c|c|c|c|c|c|c|c|}
\hline & $\begin{array}{l}\text { HD } \\
\text { SPOT-5 } \\
(150 \mathrm{~m})\end{array}$ & $\begin{array}{l}\text { HD } \\
\text { SPOT-5 } \\
(250 \mathrm{~m})\end{array}$ & $\begin{array}{l}\text { HD } \\
\text { SPOT-5 } \\
(350 \text { m) }\end{array}$ & $\begin{array}{l}\text { LG } \\
\text { SPOT-5 } \\
(150 \mathrm{~m})\end{array}$ & $\begin{array}{l}\text { LG } \\
\text { SPOT-5 } \\
(250 \text { m) }\end{array}$ & $\begin{array}{l}\text { LG } \\
\text { SPOT-5 } \\
(350 \text { m) }\end{array}$ & FD & AICc & r-adjusted \\
\hline Abundance & & & & & $\mathrm{X}$ & & $x$ & 115 & 0.55 \\
\hline Abundance & $x$ & & $x$ & & & & $X$ & 116 & 0.56 \\
\hline Abundance & $x$ & & & $x$ & & & $X$ & 117 & 0.52 \\
\hline Abundance & & $x$ & & $X$ & & & $X$ & 117.9 & 0.53 \\
\hline Abundance & & $\mathrm{X}$ & & & $x$ & & $x$ & 117.9 & 0.53 \\
\hline Abundance & & & $\mathrm{X}$ & $\mathrm{X}$ & $x$ & & $\mathrm{X}$ & 118 & 0.56 \\
\hline Abundance & & & $x$ & $\mathrm{X}$ & & $x$ & $x$ & 118.3 & 0.57 \\
\hline Abundance & & $x$ & & $x$ & & $X$ & $\mathrm{X}$ & 118.4 & 0.58 \\
\hline Abundance & $x$ & & & $x$ & & $x$ & $x$ & 118.5 & 0.58 \\
\hline Abundance & & $x$ & & $x$ & $x$ & & $x$ & 118.6 & 0.58 \\
\hline
\end{tabular}

